\title{
Finansal Kapsayıcılığın Gelişmesinde Katılım Bankacılığının Rolü: Katılım Bankacılığı Finansal Kapsayıcılık Endeksinin Hesaplanması
}

\author{
Murat Gündüz* \\ Yunus Özyıldırım**
}

\section{Öz}

Gelişmekte olan ekonomilerde tüm yetişkinlerin finansal ürün ve hizmetlere erişebildiği ve tasarruflarını finansal araçlarla sağladığı bir piyasa oluşturmak politika yapıcılar ve düzenleyiciler için bir öncelik haline gelmektedir. Dini inanışlarını gerekçe göstererek kendilerine uygun finansal ürün ve hizmetlerin bulunmadığını veya kısıtlı olarak bulunduğunu düşünen ve bundan dolayıkendilerini finansal hizmetlerden dışlayan yetişkinlerin finansal sisteme dahil edilmesi finansal kapsayıcılık boyutunun artmasında büyük öneme sahiptir. Sarma'nın (2008) literatüre kazandırdığı finansal kapsayıcılık endeksi ile bankacılık hizmetlerinin eriş̧ilebilirlik, kullanılabilirlik ve kullanım boyutları üzerinden finansal kapsayıcılığın ölçülmesi mümkün hale gelmiştir. Endeks 0 ile 1 arasında değerler almakta ve 0 finansal kapsayıcılığın dışında kalındığını 1 ise finansal kapsayıcılığın tam olarak sağlandığını göstermektedir. Bu çalışmada 2007-2019 yıllarını kapsayan Türkiye'deki 81 il için Katılım Bankacılığı için finansal kapsayıcılık endeksi oluşturulmuştur. Oluşturulan endeks değerlerinin genel olarak çok düşük olduğu tespit edilmiştir. Bu da Katılım Bankacılığının henüz illerde yeni yeni yaygınlaşmaya başlamasıyla açıklanabilir.Katıım Bankacılığı finansal kapsayıcılık endeksi değerlerine göre en yüksek finansal kapsayıcılığa sahip üç ilin İstanbul, Ankara ve Konya olduğu en düşük finansal kapsayıcılığa sahip üç ilin ise Hakkari, Artvin ve Tunceli olduğu tespit edilmiştir.

Anahtar Kelimeler: Finansal kapsayıcılık, Finansal kapsayıcılık endeksi, Katılım bankacılığı.

JEL Sınıflandırması: G15, E5, 016, P34.

\section{Abstract - The Role of Islamic Banking in the Development of Financial Inclusion: Calculation of Islamic Banking Financial Inclusion Index}

In emerging economies, creating a market where all adults can access financial products and services and provide their savings through financial instruments is becoming a priority for policy makers and regulators. The inclusion of adults who think that their financial beliefs are not available or have limited financial products and services and therefore exclude them from financial services is of great importance in increasing the financial inclusion dimension. With the financial inclusion index that Sarma's (2008) has brought to the literature, it has become possible to measure financial inclusion through the accessibility, usability and usage dimensions of banking services. The index takes values between 0 and 1 and 0 indicates that the financial inclusion is excluded and 1 indicates that the financial inclusion is fully achieved. In this study the Islamic banking for financial inclusion index of 81 provinces in Turkey, covering the years 2007 to 2019 was established. It has been determined that the created index values are generally very low. This can be explained by the fact that İslami Banking has just started to become widespread in the provinces. According to the İslami Banking financial inclusion index values, the three provinces with the highest financial inclusion were Istanbul, Ankara and Konya, while the three with the lowest financial inclusion were Hakkari, Artvin and Tunceli.

Keywords: Islamic Microfinance, Microfinance, Participation Banks, Islamic Finance, Poverty.

JEL Classification: G21, D53, D64, E44

* Uşak Üniversitesi, iktisadi ve İdari Bilimler Fakültesi, Ekonometri Bölümü - E-posta: murat.gunduz@usak.edu.tr ORCID ID: https://orcid.org/0000-0003-0006-8796

** Sorumlu Yazar, Uşak Üniversitesi, Ekonometri Yüksek Lisans Programı - E-posta: yunus-ozyildirim@hotmail.com ORCID ID: https://orcid.org/0000-0001-7198-4615

Makale Gönderim: 18.08.2020Ｍakale Kabul: 30.11.2020ＤOI: http://dx.doi.org/10.46520/bddkdergisi.841147 


\section{Giriş}

Finansal kapsayıcılık, dünya çapında çok sayıda ülkenin finansal piyasalarını ve ekonomilerini geliştirmek için uygulanan politikalar beraberinde gittikçe önem kazanan bir husus haline gelmiştir. Türkiye gibi gelişmekte olan ekonomilerin kalkınması önündeki önemli itici güçlerden biri kapsayıcı bir finansal sektördür. Katılım bankacılığında son yıllarda görülen büyümenin daha kapsayıc bir finansal piyasa oluşturulması üzerinde olumlu etki meydana getireceği düşünülmektedir. Bu kapsamda World Bank (2014) tarafından yapılan bir araştırmada katılım bankacılığının finansal kapsayıcılık üzerine pozitif etkisinin olduğu saptanmıştır. Gelişmekte olan ekonomilerde yaklaşık 2.7 milyar kişinin (yetişkin nüfusun \%70'i) finansal hizmetlere erişemediği ve bunun büyük bir kesimini demüslüman yetişkinlerin oluşturduğu ifade edilmektedir. Bu sebeble katılım bankacılığına olan ilginin finansal kapsayıcılığı geliştirmede ve ekonomik kalkınmayı güçlendirmede faydalı olacağı belirtilmektedir. Ayrıca katıım bankacılığının gelişmesinin dünya genelinde günlük geliri 2 doların altında yaşamını sürdüren 700 milyon civarındaki yoksul sayısında da azalışa yol açacağı iddia edilmektedir (Mohieldin vd. 2011: 9).

Finansal hizmetlere erişimi ölçmek amacıyla yapılan analizlerde müslüman nüfusun yoğun olduğu birçok ülkenin finansal sektöründe son yıllarında kaydedilen büyüme rakamlarına rağmen yetişkin nüfusun hala istenilen oranda finansal ürün ve hizmetlere dahil edilemediği gözlenmiştir (Burgess ve Pande 2004: 4). Müslüman nüfusun yoğun olduğu ülkelerde finansal kapsayıcılık endeksinin düşük olduğu görülmektedir. Bu durumun sebepleri olarak dini inançlar, finansal hizmetlere erişim mesafesi ve yeterli bilginin olmaması gibi nedenler öne sürülmektedir (Işık, 2011: 2). Crabtree (2010) Gallup 2010 anket verilerine dayanarak, İslam İşbirliği Örgütü (iiO) üye ülkelerinde yaşayan yetişkin nüfusun \%90'ının dini günlük hayatlarının önemli bir parçası olarak gördüklerini ifade etmektedir. Bu oran Türkiye için \%82'dir (Gallup, 2010). Bu oranlar finansal kapsayıcılığın geliştirilmesinde ve bütünüyle kapsayıc bir finansal sistem oluşturma hedefi için tüm kullanıcıların finansal ürün ve hizmetlere erişebilmesinin önündeki engelleri iyileştirmek ve yetişkin bireylerin dini ve kültürel hassasiyetlerine karşı dikkatli olunması gerektiğini ortaya koymaktadır. Tasarrufların finansal kuruluşlar aracılığıyla gerçekleştirildiği, kredi kullanabilirliğinin arttığı ve finansal hizmetlere erişimin kolay olduğu bir ekonominin özellikle küçük ve orta ölçekli işletmeler için sürdürülebilir büyümeyi kolaylaştırabileceği belirtilmektedir (Demirgüç-Kunt ve Klapper, 2012: 19). Finansal kapsayıcılığın geliştirilmesi ekonomik kalkınma için bir itici güç olmanın yanında yoksulluğu ve gelir eşitsizliğini azaltmada oldukça önemli bir yere sahiptir. Nitekim finansal kapsayıcılığın katıım bankacılığının 
gelişmesiyle daha da artacağı düşünülmektedir.(Beck, Demirgüç-Kunt ve Martinez Peria, 2006: 8)

2019 yılının Kasım ayında İslami Finansal Hizmetler Kurulu (IFSB-Islamic Financial Services Board) tarafından yayınlanan "Sorumlu Finans-Etik ve İslami Finans Küresel Gündemi Yakalama" adlı raporda finansın temel amacının ekonomiyi güçlendirme olduğu üzerinde durulmaktadır. Finansın reel ekonomiye katkı sağlamak amacıyla geliştirildiği belirtilerek sonuca ulaşmada kullanılan bir araç olduğu ifade edilmektedir. Bu raporun sonuç bölümünde ise etik finans ve İslami finans sorumlu finansal dallar olarak nitelendirilmektedir. İslami finans ve etik finansın güçlü ortak benzerliklere sahip olduğu söylenmektedir (IFSB, 2019). Benzer şekilde Birleşmiş Milletler Kalkınma Programı́nın (UNDP) 2019 yılında yayınladığı "İslami Finans ve Etkili Yatırım Raporu" başlıklı raporunda Konvansiyonel Etki Düşünceleri, Etkili Yatırım Evreni, İslam Hukuku'nun Temelleri, İslami Yatırım Evreni, Örtüşen Alanlar ve Büyüme Stratejileri gibi başlıklar ele alınarak İslami finansın ve yayılımının ekonomik kalkınma üzerindeki etkileri incelenerek ekonomiler için öneminden bahsedilmektedir (UNDP, 2019). Bu programlar aracılığıyla İslami finansın gelişiminin finansal kapsayıcılığı artıracağı beraberinde de ekonomik anlamda gelişmenin bir parçası olacağı düşünülmektedir.

Bu çalışmanın ilk bölümde finansal kapsayıcılık ve finansal erişim temeline dayanan finansal kapsayıcılık endeksi üzerine araştırmalara yer verilerek konu derinlemesine incelenmiştir. Ikinci bölümde finansal kapsayıcılık endeksi yöntemi ele alınmıştır. Üçüncü bölümde Sarma'nın(2008: 5)'deki çalışmasında literatüre kazandırdığı finansal kapsayıcılığı ölçen finansal kapsayıcılık endeksi kullanılarak Türkiye için katılım bankacılığının finansal kapsayıcılık boyutu ölçülmüştür. Bu çerçevede Bankacılık Düzenleme ve Denetleme Kurulu (BDDK) tarafından yayınlanan veriler kullanılarak Türkiye'nin 81 ili için 2007 - 2019 yıllarını kapsayan katılım bankacılığının finansal kapsayıcılık endeksi (KBFKE) hesaplanmıştır. Elde edilen endeks, bankacılık hizmetlerinin erişebilirliği ve kullanımı gibi çeşitli bankacılık sisteminin boyutları hakkında bilgiler içermektedir. Hesaplanan endeks bankacılık hizmetlerinin her boyutunu 0 ile 1 arasında değer haline getirmekte, 0'a yaklaştıkça finansal kapsayıcılığın dışında kalındığını, 1'e yaklaşıldıkça ise finansal kapsayıcılığın gittikçe genişlediğini göstermektedir.0 kapsayıcılığın olmadığı bir piyasayı 1 ise tam kapsayıcılığı ifade etmektedir. Son olarak bulgular yorulanarak Türkiye'nin katılım bankacılığının finansal kapsayıcılık boyutu üzerine değerlendirmelerde bulunulmuştur.

M. Gündüz, Y. Özyıldıım, "Finansal Kapsayıcılığın Gelişmesinde Katııım Bankacılığının Rolü: Katılım Bankacılığı Finansal Kapsayıcılık Endeksinin Hesaplanması”, BDDK Bankacilık ve Finansal Piyasalar Dergisi, 14, (2), 2020, 119-144 


\section{Literatür Taraması}

Bankacılık sektörünün oluşması, finansal piyasaların büyümesi ve gelişmesine katkı sağlamış aynı zamanda daha fazla kişiye daha geniş finansal ürün ve hizmet yelpazesine erişim imkânı sunmuştur. Kempson (1994), 1970'lerin ortalarında İngiltere'deki hane halklarının yarısından azının herhangi bir finansal kuruluşta hesabının olduğunu bildirmektedir. Bununla birlikte 1970'lerin başlarında hane halklarının yaklaşık dörtte birinin kredi hizmetlerine erişim hakkına sahip olduğunu bu rakamın on yıl içinde dörtte üçlük seviyelere çıktığını ifade etmektedir. Kempson \& Whyley (1999: 10), bu gelişmeleri tetikleyen iki temel hususun ise finansal hizmet sektörünün deregülasyonu ve risk değerlendirmesi için bilgi teknolojisinin uygulanmasındaki gelişmeler olduğunu tespit etmiştir. Öte yandan çalışmalarında, bir banka hesabına sahip olmak veya sigorta gibi en temel finansal ürünlerden bile yoksun gruplar olduğunu saptamışlardır. Bu grupların finansal piyasalar içinde çok fazla hizmet alamayan kesim olarak finansal dışlanmadan daha düşündürücü bir mesele olan finansal hizmetlere katılımın sınırlı olması durumu ile yüz yüze oldukları ortaya koyulmuştur. Finansal kapsayıcılıktaki sınırlılıklar, finansal piyasaların yanı sıra hem ABD'de hem de Avrupa'da ekonomik ve sosyal bir sorun olarak görülmüş ve giderilmesi için çaIışmalar arttırılmıştır (Zhijun, 2007: 2). Özellikle gelişmekte olan ekonomiler, genel stratejilerinin bir parçası olarak, finansal piyasaların istikrarlı gelişimi için düşük gelirli hane halkı ve firmaların finansal hizmetlere daha fazla erişimini yani finansal kapsayıcılığı arttırmayı hedeflemektedir (Morgan ve Pontines, 2014: 7). Kapsayıcılığı yüksek bir finansal piyasada tasarrufların finansal kuruluşlar aracılığıyla sağlanması ve kredi kullanılabilirliğinin artması, sürdürülebilir ekonomik kalkınmada önemli bir etken olarak görülmektedir. Finansal erişimin ölçülmesine yönelik olarak Honohan (2007: 10), araştırmasında 160' dan fazla ülke için hane halkı anketi ile birlikte bankalar ve küçük finans kurumlarından elde ettiği verileri kullanarak, finansal hizmetleri kullanan hanelerin oranını tespit etmeye çalışmıştır. Araştırmacı ankette özellikle finansal varlıkların sayılarını değil finansal hizmetlere erişimin olup olmadığını belirlemeyi hedefleyen sorular üzerine yoğunlaşmıştır. Elde edilen veriler kullanılarak banka hesaplarını toplam nüfusa, anketlere dayalı erişimi ortalama mevduat büyüklüğüne ve ülke verilerini de kişi başına GSYH'ye oranlanmıştır. Daha sonra Gini Katsayısı kullanılarak bu oranları ekonometrik olarak yoksulluk ve gelir eşitsizliği arasındaki ilişkiyi incelemiş̧tir. Çalışma sonucunda yoksulluk ile finansal kapsayıcılık arasında ters yönlü bir ilişkili olduğu yine Gini Katsayısı ile ölçülen gelir eşitsizliği ile arasında da negatif yönde bir ilişkili olduğu ortaya koyulmuştur.

Aynı doğrultuda Beck vd. (2005: 25) finansal gelişimin gelir dağılımı ile yoksulluk 
üzerindeki etkisini araştırmıştır. Çalışmada, geniş bir literatür taramasından sonra finansal gelişimin, yoksulluğun azaltılması ve gelirin arttırılması üzerinde pozitif yönlü bir etkisinin olduğu sonucuna varılmıştır. Yoksulluk ve gelir birlikte değerlendirildiğinde finansal gelişimin etkisi yoksulluğu azaltmada gelir artışına nazaran daha yüksek seviyededir. Dolayısıyla gelir eşitsizliğinin hızlı bir şekilde ortadan kaldırılmasında büyük öneme sahip olduğu sonucuna varılmıştır.

Finansal gelişimin ölçülebilmesi amacıyla yapılan çalışmalar çok boyutlu olarak finansal kapsayıcılığın araştırılmasına zemin oluşturmuştur. Sarma (2008: 5) ise finansal kapsayıcılık üzerine yapılmış çalışmalar olmasına rağmen finansal kapsayıcılığın boyutunu ölçen hiçbir çalışmanın olmamasına dikkat çekmiş ve dünya üzerinde iyi bilinen İnsani Gelişmişlik Endeksi (HDI), İnsani Yoksulluk Endeksi (HPI) ve Gayri Safi Milli Gelir (GDI) gibi endekslerin oluşturulmaları ile benzerlik gösteren bir yapıda Finansal Kapsayıcılık Endeksini (FKE) geliştirerek literatüre kazandırmıştır. FKE, finansal kapsayıcılığın göstergeleri olarak bilinen bankacılık verilerinin (kişi başına ATM ve şube sayısı, kredi kullanım ve mevduat miktarı, mevduat hesabı sayısı) çeşitli boyutlarının dikkate alındığı, 0 ile 1 arasında bir değer alabilen çok boyutlu bir endekstir. Oluşturulan bu endeks finansal kapsayıcılığın boyutlarının ortaya koyulmasına ve yeni araştırmaların yapıımasına olanak sağlamıştır.

Arora (2010: 4) bu çalışmalardan birine imza atarak Sarma (2008: 5)'nın önerdiği endeksi incelemiş ve finansal kapsayıcılığı ölçmede eksik yönlerinin olduğu kanısına varmıştır. Endekse sosyal yardım, işlem kolaylığı ve işlem maliyetleri ile ilgili değişkenleri de dâhil ederek yeni bir sosyo-ekonomik finansal kapsayıcılık endeksi oluşturmuştur. Gupte vd. (2012: 136) oluşturulan finansal kapsayıcılık endekslerini inceleyerek Sarma (2008: 5) ve Arora (2010: 5)'nın finansal kapsayıcılık endeksi hesaplamalarında bir veya daha fazla boyutun eksik olduğunu belirtmektedir. Mümkün olduğunca çok boyutlu bir endeksin daha kapsamlı bir finansal kapsayıcılığın ölçülmesiyle sonuçlanacağını ifade etmektedir. Dünya Bankasının 2009 ve 2010 yıllarında yayınlamış olduğu verileri kullanarak UNDP'nin HDI'yı 2010'da hesaplarken kullandığı yöntemi kullanarak dört kritik boyutu (erişebilirlik, kullanım, işlem kolaylığı ve işlem maliyetini) esas alan yeni bir finansal kapsayıcılık endeksi oluşturmuştur. Ancak finansal kapsayıcılığın gelişim sürecinde bazı eksiklerin var olduğunu söyleyen Dünya BankaSı araştırmacıları Demirgüç-Kunt \& Klapper (2012: 20) finansal kapsayıcılık üzerine yaptıkları araştırmada sadece bankalar ve küçük finans kuruluşları üzerine çalışmalar yapıldığını belirterek bu durumu bir eksiklik olarak görmüşlerdir. Bu boşluğu doldurmak amacıyla finansal kapsayıcılığın bireyler üzerindeki etkisini ülkeler bazında araştırmışlardır. 148 ülkede yetişkinlerin nasıl tasarruf yaptıklarını, borç aldıklarını, ödeme

M. Gündüz, Y. Özyıldırım, “Finansal Kapsayıcılığın Gelişmesinde Katııım Bankacııı̆ııın Rolü: Katııım Bankacılığı Finansal Kapsayıcılık Endeksinin Hesaplanması”, BDDK Bankacilık ve Finansal Piyasalar Dergisi, 14, (2), 2020, 119-144 
yaptıklarını ve riski nasıl yönettiklerini ölçen 150.000'e yakın veri kümesi olan Dünya Bankası Global Findex veri tabanını oluşturmuşlardır. Çalışmada ülkelerin finansal kapsayıcılık boyutu hakkında bilgiler verilerek bölgesel ve bireysel farklııkların olduğu gösterilmiştir. Araştırmacılar, bu farklılıkların oluşmasında en önemli etkenler olarak yüksek maliyet, mesafe, uygun verilerin bulunmaması ve dini gerekçeleri gereği piyasa dışında kalan bir kesimin olduğunu tespit etmişlerdir. Nitekim Demirguc-Kunt vd. (2013: 10) çalışmalarında, endeksin hesaplandığı ülkelerde Müslümanlar ile Müslüman olmayanlar arasında bir farklılık olduğu tespit edilerek bu finansal kapsayıcılık farklılığının talep yönlü mü yoksa arz yönlü mü olduğunu araştırmışlardır. Çalışmada, Gallup araştırma şirketinin 64.000'den fazla kişi üzerinde uygulamış olduğu Dünya Anketinde yer alan Katılım Bankacılığını esas alan sorulardan da faydalanılarak resmi bir finansal hesaba sahip olma ve resmi bir finansal kurumda tasarruf etme oranları incelenmiştir. Finansal kapsayıcılık endeksi hesaplanan ülkelerde Müslümanların resmi bir hesaba sahip olma ve resmi bir finansal kurumda tasarruf etme oranının Müslüman olmayanların oranına göre önemli derecede düşük olduğu tespit edilmiştir.

Katılım Bankacılığı kaynaklı finansal hizmetlerin kullanımı ve bunun finansal kapsayıcılık ile arasındaki ilişkisini inceleyen Dünya Bankası (2014) raporunda, dini sebeplerden dolayı kendini finansal piyasaların dışında tutarak finansal ürün ve hizmetlere erişemeyen 40 milyondan fazla kişi üzerine incelemede bulunulmuştur. Müslüman nüfusun yoğun olarak yaşadığı ülkelerde, finansal sektörün büyümesine rağmen birçok kişinin ve firmanın hâlâ finansal açıdan bu hizmetlere dâhil olmadıkları sonucuna varılmıştır. Yetişkinler ve firmalar üzerinden yapılan analiz sonucunda ise birçok Müslüman ülkenin gelişmekte olan ülkelerin gerisinde kaldığı ve sadece \%27' lik bir kesimin finansal anlamda kapsayıcı olduğu saptanmıştır. Araştırma sonucunda finansal hizmetlere erişimin önünde dini gerekliliklerin engel olarak görülmesi yanında uzaklık, veri eksikliği ve güven unsurlarının da önemli olduğu ortaya koyulmuştur. Aynı doğrultuda Naceur vd. (2015: 11) çalışmalarında, Katılım Bankacılığının varlığı ve faaliyeti ile finansal kapsayıcılık arasındaki ilişkiyi incelemişlerdir. Öncelikle Katıım Bankacılığının gelişiminin Müslüman ülkelerde finansal kapsayıcılığın artması ile ne derecede ilişkili olduğu incelenmiştir. Bu amaca yönelik olarak IMF'nin FAS (Financial Access Survey) ve Dünya Banka'sının Global Findex veri tabanları kullanılarak özellikle işletmelere yönelik yapılan anketten elde edilen değişkenler incelenmiştir. Yapılan araştırma kapsamında, İslam İşbirliği Teşkilatı (iiT) ülkeleri arasında finansal hizmetlere erişimin daha hızlı artmasına rağmen, finansal kapsayıcılık açısından bakıldığında dünya genelinin oldukça altında oldukları görülmüştür. Araştırmacılar iiT ülkelerinde dini açıdan kendilerini finansal kapsayıcılık alanının dışında tutmak isteyen bireylerin 
çok sayıda olduğunu ve bu durumun nedeni olarak ta birçok iiT ülkesinde Katılım Bankacılığının yeterince gelişmemiş olduğu sonucuna varmışlardır. Finansal kapsayıcılığın gelişmesine yönelik uygulanan stratejiler açısından değerlendirmelerde bulunan Zulkhibri (2016: 315) çalışmasında, 13 Müslüman ülkenin son zamanlarda uygulamış oldukları finansal kapsayııılık stratejilerini ve hedeflerini değerlendirmektedir. Çalışmada detaylı bir şekilde incelenen Malezya, Endonezya, Nijerya ve Bangladeş gibi ülkelerin finansal kapsayııılık yönünden yenilikçi yollar belirlediği saptanmışır. Finansal kapsayıcılığın geliştirilmesi için yapılan yeniliklerin ve belirlenen hedeflere ulaşmanın, yoksulluğun azaltılması ve bu ülkelerdeki refah düzeyinin artırımasında rolünün önemli olduğu tespit edilmiştir. Bununla birlikte Katıım Bankacılığının sunduğu finansal hizmetlerin sınırlı olduğunu belirterek bu durumun güçlendirilmesi için arz ve talep tarafını ele alan 6 politika önerilmiştir.

Katılım Bankacılığına farklı bir bakış açısı getiren Mohieldin vd. (2011: 12) küçük ve orta ölçekli işletmeler için kapsayıcılık meselesini iki yönden ele almaktadır. Illki geleneksel borç temelli finansmana uygun bir alternatif sunan kâra veya zarara ortaklık, diğeri ise servetin toplum tarafından yeniden dağıtılması için özel araçlarla desteklenmesidir. Bunlar Katılım Bankacılığı hizmetleri arasında olanlardan Zakah, Sadaka, Waqf ve Qard-al-Hasan gibi dağıım araçlarıdır. Yeniden dağııım araçlarının yoksulluğun ortadan kaldırımasına ve gelişen bir ekonomi inşa etmek için birbirlerini tamamladıkları sonucuna varılmışıı. İslam'ın gerçek bir ruh haliyle uygulanması halinde yoksulluk içinde yaşanan Müslüman ülkelerde yoksulluğun ve gelir eşitsizliğinin azalmasına neden olacağı ortaya koyulmaktadır.

Konuyla yakından ilişkili literatüre katkı sağlayan çalışmalar (Yorulmaz, 2013; Er vd. 2016; Gündüz ve Özyıldııım, 2019; Seven vd. 2020) incelendiğinde Yorulmaz (2013) tarafından Türkiye'nin 2004-10 yılları için 80 ilin mevduat bankacılığının finansal kapsayıcılık endeksini hesaplamıştır. Çalışmada endeks değerleri İstanbul ayrı bir bölge olarak ele alınarak elde edilmiştir. Dolayısıyla birçok ilin yüksek finansal kapsayıcılık düzeyine sahip olduğu gözlenmiştir. Bunun yanında Gündüz ve Özyıldırım (2019) yaptıkları çalışmada mevduat bankacılığının finansal kapsayıcılık endeksini 2011-2018 yıllarında arasında tüm iller için ortaya koymuştur. Bu çalışmada endeks değerlerinde Yorulmaz (2013) çalışmasına göre farklılıkların olduğu gözlenmiştir. Böylece il bazlı hesaplamaların sonuçları değerlendirmede nüfusa oranlanan verilerden yararlanılmış ve illerin mevduat bankacılığının finansal kapsayıcılık endeksi değerleri ortaya koyulmuştur. Benzer şekilde Er vd. (2016) yaptıkları çalışmalarında Türkiye'nin 12 bölgesi ve 80 ili için hem mevduat hem de katılım bankacılığı verilerini kullanarak 2009-2015 yılları için iki farklı finansal erişim endeksi oluşturup inceleme-

M. Gündüz, Y. Özyıldııım, “Finansal Kapsayıcııı̆ın Gelişmesinde Katıım Bankacılığının Rolü: Katııım Bankacılığı Finansal Kapsayıcılık Endeksinin Hesaplanması”, BDDK Bankacilık ve Finansal Piyasalar Dergisi, 14, (2), 2020, 119-144 
lerde bulunmuşlardır. Yine Seven vd. (2020) araştırmalarında farklı gelir gruplarını içeren ülkeler ile Türkiye'nin finansal kapsayıcılık değerlerini karşılaştırmalı olarak incelemiştir. Bu araştırmayla bölgesel bazlı değerlendirmelerde bulunularak finansal kapsayıcılığın geliştirilmesi yönünde sonuçlar ortaya koyulmuştur.

\section{Finansal Erişim ve Finansal Kapsayıcılık}

Son on yılda hızla gelişen teknolojik yenilikler, finansal erişimndeki ilerlemeyi hızlandırmaktadır. Mobil bankacılık, Kenya, Filipinler ve Tanzanya gibi düşük gelirli ülkelerde finansal erişimin genişletilmesinde anahtar rol oynamıştır. Brezilya, teknoloji kaynaklı "mobil bankacılık" tarafından finanse edilen hizmetler sunarak uzak bölgelerde yaşayan insanlarda finansal erişimi arttırmıştır. Dünya Bankası raporuna göre düşük gelirli nüfusa sahip ülkelerde mobil ödemeler ve mobil bankacılık gibi teknolojik yenilikler çok faydalı olmuştur. Bunun nedeni bu yeniliklerin finans hizmetlerini yoksullara, kadınlara, kırsal kesimde yaşayanlara ve özellikle de banka şubelerinin olmadığı daha az nüfuslu bölgelerde yaşayan insanlara daha ucuz ve daha kolay erişimi sağladığı yönündedir (Demirgüç-Kunt, 2015: 24).

Milyonlarca banka hesabı oluşturmak, düzenli olarak kullanılmazsa çok az etkiye sahip olur ve maliyet dikkate almadan krediyi teşvik etmek aslında finansal ve ekonomik istikrarsızlığı arttıran bir etkiye dönüşür. Bu yüzden finansal okur-yazarlık hakkında yeterli bilgi donanımına sahip olunması önemli bir husustur. Tüm yetişkinlerin bilinçli bir şekilde tasarruf edebilir durumda olmaması finansal piyasalara fon akışının sağlanmasını güçleştirmektedir. Finansal ürün ve hizmetlere erişebilen yetişkinler, tasarruflarını finansal piyasalar aracılığıyla gerçekleştirip sistemin dışında kalan fonu piyasaya kazandırmaktadır.Tasarruflarını erişebildikleri finansal araçlarla gerçekleştiren yetişkinler finans sektörün gelişmesine ve sürdürülebilir ekonominin sağlam adımlarla ilerlemesine öncülük ederler.

Ekonomik olarak güçlenmenin ve yoksulluğun ortadan kaldırılmasına yardımcı olmada finansal atılımlar büyük bir önem arz etmektedir. Bu doğrultuda alınan kararlar, bireylerin finansal ürün ve hizmet yelpazesine erişiminin önündeki engelleri açmaya yönelik olması gerekmektedir.Nitekim toplumun her kesimini finansal piyasalara dâhil etmek üzere alınan kararlar, finansal kapsayıcılığın gelişiminde büyük bir katkı ortaya koymaktadır. Finansal kapsayıcılığı ilk olarak araştıranlardan biri olan Chakravarthi(2008), korumasız ve gelir seviyesi düşük grupların finansal ürün ve hizmet yelpazesine ihtiyaç duydukları anda en düşük maliyetle ve zamanında bu hizmetlerin sağlanması olarak belirtmiştir. Bu doğrultudan yola çıkarak Sarma (2008: 5) yılında finansal kapsayıcılık endeksini literatüre kazandırmış ve finansal kapsayıcılığı, 
kamu ve özel sektörün içerisinde bulunduğu tüm finansal sisteme erişim ve kullanım kolaylığının sağlanması olarak ifade etmiştir.

Finansal kapsayıcılığı ölçmek amacıyla geliştirilen finansal kapsayıcılık endeksi, finansal ürün ve hizmet göstergelerini dikkate alarak hesaplanan çok boyutlu bir endekstir. Bu endeks ile finansal hizmetlerin erişilebilirliği (ATM, şube sayıları vb.), kullanılabilirliği (hesap sayısı vb.) ve kullanımı (mevduat ve kredi miktarları vb.) gibi finans sisteminin çeşitli boyutları hakkında bilgiler verilmektedir. Finansal kapsayıcılık endeksi hesaplanırken belirtilen boyutların her biri 0 ile 1 arasında değerlere dönüştürülerek o boyutun finansal kapsayıcılık üzerinde ne ölçüde etkili olduğu belirlenmiş olur. Bu amaçla hesaplanan değerler 0'a yaklaştıkça finansal kapsayıcılığın azaldığı, 1'e yaklaştıkça ise finansal kapsayıcılığın arttığı ifade edilmiş olmaktadır. Böylece oluşturulan bu boyut değerleri bir araya getirilerek genel finansal kapsayıcılık endeksi oluşturulmuş olur (Sarma, 2010: 15). Bu sayede hesaplanan finansal kapsayıcilık endeksi ile çeşitli birimler arasındaki (ülkeler, iller vb.) farkların görülmesine ve karşılaştırılabilir sonuçlar ortaya koyulmasına imkân tanınmaktadır.

Finansal kapsayıcılık endeksinin hesaplanmasında dikkate alınan boyutlardan ilki olan Finansal Hizmetlere Erişilebilirlik (accessibility), şube ve ATM sayısının coğrafik ve demografik tabanda ülke içindeki dağılımını göstermektedir (Dünya Bankası, 2005). Coğrafik olarak ele alınan şube ve ATM sayıları, kullanıcıların en yakın bankacılık hizmeti sağlayan birime ortalama ne kadar uzakta olduğunu göstermektedir. Demografik olarak ele alınan şube ve ATM sayıları ise bir şubenin ve/veya ATM'nin ne kadar kullanıcıya hizmet verdiğini ölçmektedir.

Finansal kapsayıcılık endeksinin hesaplanmasındaki ikinci boyut olan Finansal Hizmetlerin Kullanılabilirliği (availability), bir banka hesabına sahip olanların sayısını ifade etmektedir. 100.000 yetişkin başına düşen banka hesabına sahip kişi sayısı finansal anlamda bankacılık hizmetlerinin ne düzeyde kullanılabildiğini ölçmek için kullanılan bir göstergedir.

Finansal hizmetlerin yaygınlığını gösteren finansal kapsayıcılık endeksinin hesaplanmasındaki üçüncü boyut olan Finansal Hizmetlerin Kullanımı (usage), finansal sistem içerisinde kişi başına düşen mevduat ve kredi miktarını belirtmektedir (Dünya Bankası, 2005). Aynı zamanda bu boyut, kredi ve mevduatın vatandaşlar tarafından ne ölçüde kullanılabildiğini ve kullanılan kredi miktarının geri ödenmesinde hangi ölçüde ödeme gücüne sahip olunduğunun bir göstergesidir.

Literatürde yer alan bazı araştırmalar (Beck vd., 2005: 22; Peachey \& Roe, 2006).

M. Gündüz, Y. Özyıldııım, “Finansal Kapsayıcılığın Gelişmesinde Katııım Bankacılığının Rolü: Katılım Bankacılığı Finansal Kapsayıcılık Endeksinin Hesaplanması”, BDDK Bankacilık ve Finansal Piyasalar Dergisi, 14, (2), 2020, 119-144 
Finansal kapsayıcılık endeksinin hesaplanmasında söz konusu boyutlara ait tüm göstergeleri elde etmenin mümkün olamadığı veya bu göstergelerin genel itibariyle mevduat bankalarının ürün ve hizmet yelpazesini içerdiği noktasında eleştiride bulunmuşlardır. Bir başka ifadeyle, diğer finansal kurumların (Katıım Bankaları, Kalkınma ve Yatırım Bankaları, Posta Bankaları, Sigorta Şirketleri vb.) verdiği hizmetlerinin dikkate alınmaması bir eksiklik olarak değerlendirilmektedir.Türkiye'de bankacılık sektörü göz önüne alındığında 2019 yılında genel içerisinde Mevduat Bankacılığının payının \% 89, Katılım Bankacılığının payının \% 8 ve Kalkınma ve Yatırım Bankacılığının payının ise \% 3 olduğu görülmektedir (TBB- Bankaların Aktiflere Göre Sektör Payları, 2019). Bu durum Türkiye'de bankacılık faaliyetleri içerisinde mevduat bankacılığının payının oldukça yüksek olduğunu göstermektedir. Finansal kapsayıcılık endeksini mevduat bankaları verileri üzerinden hesaplamak resmin büyük ölçüde bu kısmının görülmesine olanak tanımaktadır. Ancak Gallup Finansal Kapsayıcılık Dünya Anketi verilerine göre, İslam İşbirliği Teşkilatı (iiT)'ye üye ülkelerde yaşayan yetişkin nüfusun \% 90' dini günlük hayatlarının önemli bir parçası olarak görmektedir. Bu oran Türkiye için \% 82'dir (Crabtree, 2010: 31). Aynı zamanda, finansal sistemin dışında kalan yetişkinlerin oranı incelendiğinde Hollanda'da \% 0, Almanya'da \% 3 ve Ingiltere'de \% 9 iken bu oran Türkiye'de \% 51'dir. Buna göre Türkiye'de iki kişiden birinin finansal sistemin dışında olduğu değerlendirilmektedir (Işık, 2011: 2). Bununla birlikte gelişmekte olan ekonomilerde de 2.7 milyar kişi (yetişkin nüfusun \% 70'i) finansal hizmetlere erişememekte ve bunun büyük bir kesiminin müslüman kişilerden oluştuğu bilinmektedir(Demirgüç-Kunt, 2015: 24).

Katılım Bankacılığına olan ilginin finansal kapsayıcılığı geliştirmede ve ekonomik kalkınmayı güçlendirmede faydalı olacağı belirtilmektedir. Bu bağlamda Katılım Bankacılığına olan ilginin artması beraberinde dünya genelinde günlük 2 doların altında yaşayan 700 milyona yakın yoksul kesimi azaltan bir etki gösterecektir (Mohieldin, 2011: 9). Dünya Bankası (2014) tarafından yapılan analiz sonucunda ise Katıım Bankacılığının finansal kapsayıcllık üzerine pozitif bir etkisinin olduğu da ortaya koyulmuştur.

\section{Finansal Kapsayıcılığın Ölçülmesi}

Finansal kapsayıcılık tek parçalı bir yapı olmamakla birlikte bir banka hesabına sahip olmaktan başlayıp modern bankacılık araçlarına kadar giden çok katmanlı bir sistem içinde incelenmesi gerekmektedir. Her katmanı oluşturan bir değişken finansal piyasaların farklı özelliğini temsil etmektedir. Oluşturulan endeks değerleri ile de her katmanı kapsayan çok boyutlu bir endeks değeri elde edilerek finansal hizmetlerin erişilebilirliği ve kullanımının hakkında net bilgiler verilmektedir (Sarma ve Pais, 2011: 615). 
Tablo 1. Dünya Bankası (2005) Endeks Ölçüm Verileri

\begin{tabular}{|l|l|l|}
\hline $\begin{array}{l}\text { 1-Şube } \\
\text { 2-ATM }\end{array}$ & Coğrafik & $\begin{array}{l}1.000 \text { kilometreye düşen şube sayısı } \\
1.000 \text { kilometreye düşen ATM sayısı }\end{array}$ \\
\hline 3-Şube & & 100.000 kişi başına düşen şube sayıSı \\
5-Kredi & Demografik & 100.000 kişi başına düşen ATM sayısı \\
6-Mevduat & & 1.000 Kişi başına düşen kredi miktarı \\
\hline 7-Kredi & GSYH(\%) & Kredin GSYH içindeki payı \\
8-Mevduat & & Mevduatın GSYH içindeki payı \\
\hline
\end{tabular}

Kaynak: Dünya Bankası, 2005.

Finans sektöründeki hizmetlerin ölçülmesine yönelik ilk girişim olarak değerlendirilen Beck vd. (2005: 44) çalışmalarında bankacılık sektörünün kapsayıcılığını en kapsamlı şekilde ölçmek için finansal hizmetlerin belirleyicilerini araştırmaktadırlar. 2003-2004 yılına ait finansal hizmetlere katıımın coğrafik ve demografik erişilebilirliğine ilişkin aşağıdaki sekiz göstergenin verilerini kullanarak finansal kapsayıcılığın resminin görülmesine olanak tanımaktadırlar.

Tablo 1'deki göstergelerden (1) ile (4) arasındaki değişkenler, finans sektörünün fiziki erişim olanakları açısından erişim boyutunu ölçmeye yarayan göstergelerken, (5) ile (8), bankacılık hizmetlerinin kullanımını ölçen göstergelerdir. Bir diğer çalışmalarında Beck vd. (2007: 2) bankacılık hizmetlerini etkileyen diğer faktörleri ve bankacılık hizmetlerine erişimin ve kullanımın önünde yatan engelleri incelemek için aynı boyutları ve göstergeleri kullanmışlardır.Literatürde yapılan çalışmalar incelendiğinde kimi çalışmalar benzer göstergelerle finansal kapsayıcılığı ortaya koyarken kimi çalışmalar da farklı bakış açılarıyla kapsayıcılığı hesaplamıştır. Kimi yazar için sosyo-ekonomik açıdan değerlendirilirken kimi yazar tarafından da finansal piyasaların araştırılması için geliştirilmiştir.Seman (2006) tarafından oluşturulan Tablo 2'nin incelenmesi bu durumu daha anlaşılır hale getirmektedir. 
Tablo 2. Finansal Kapsayıcılık Endeksinin Ölçümü İçin Boyut ve Göstergelere İlişkin Çalışmaların Özeti

\begin{tabular}{|c|c|c|c|c|c|c|}
\hline \multirow{3}{*}{ Yazarlar } & \multirow{3}{*}{$\begin{array}{l}\text { Finansal } \\
\text { hizmetler }\end{array}$} & \multicolumn{5}{|c|}{ Boyutlar } \\
\hline & & \multicolumn{2}{|c|}{ Sosyal Yardım } & \multirow{2}{*}{ Kullanım } & \multirow{2}{*}{$\begin{array}{l}\text { Kolaylaş- } \\
\text { tırmak }\end{array}$} & \multirow{2}{*}{ Maliyet } \\
\hline & & Erişebilirlik & Kullanılabilirlik & & & \\
\hline $\begin{array}{l}\text { Beck, } \\
\text { Demirguc- } \\
\text { Kunt, \& } \\
\text { Martinez } \\
\text { Peria } \\
(2007: 3)\end{array}$ & Bankacılık & $\begin{array}{l}\text { * Demografik } \\
\text { şube nüfuzu } \\
\text { (100.000 kişi } \\
\text { başına Banka } \\
\text { şubesi sayısı) } \\
\text { * Demografik } \\
\text { ATM nüfuzu } \\
\text { (100.000 kişi } \\
\text { başına Banka } \\
\text { ATM'si sayısı) }\end{array}$ & $\begin{array}{l}\text { * Coğrafi nü- } \\
\text { fuz (1.000 m2 } \\
\text { başına Banka } \\
\text { şubesi sayısı) } \\
\text { * Coğrafi nüfu- } \\
\text { zu (1.000 m2 } \\
\text { başına Banka } \\
\text { ATM'si sayısı) }\end{array}$ & $\begin{array}{l}\text { * Kredi göstergeleri: } \\
\text { i. Kişi başına kredi } \\
\text { miktarları: } 1.000 \text { kişi } \\
\text { başına kredi sayısı } \\
\text { ii. Kredi-gelir } \\
\text { oranı: Ortalama } \\
\text { kredi büyüklüğü } \\
\text { * Mevduat göster- } \\
\text { geleri: } \\
\text { i. Kişi başına mevdu- } \\
\text { at hesapları: } 1.000 \\
\text { kişi başına mevduat } \\
\text { sayısı } \\
\text { ii. Mevduat-gelir } \\
\text { oranı: Mevduatın } \\
\text { kişi başına düşen } \\
\text { GSYiH'ye oranı }\end{array}$ & $\begin{array}{l}\text { Dikkate } \\
\text { alınmadı }\end{array}$ & $\begin{array}{l}\text { Dikkate } \\
\text { alınmadı }\end{array}$ \\
\hline $\begin{array}{l}\text { Honohan } \\
\text { (2007: } 7 \text { ) }\end{array}$ & $\begin{array}{l}\text { Bankacilık } \\
\text { ve Mikrofi- } \\
\text { nans }\end{array}$ & $\begin{array}{l}\text { * Demografik } \\
\text { Banka nüfuzu } \\
\text { (100 yetişkin } \\
\text { başına Banka } \\
\text { hesabı sayısı) } \\
\text { * Demografik } \\
\text { MFI'lar ve } \\
\text { alternatif ara- } \\
\text { cıların nüfuzu } \\
\text { (MFI'larda } \\
\text { hesap sayısı ve } \\
100 \text { yetişkin } \\
\text { için alternatif } \\
\text { aracılar) }\end{array}$ & $\begin{array}{l}\text { Dikkate alın- } \\
\text { madı }\end{array}$ & $\begin{array}{l}\text { * Ortalama Banka } \\
\text { mevduat büyüklüğü }\end{array}$ & $\begin{array}{l}\text { Dikkate } \\
\text { alınmadı }\end{array}$ & $\begin{array}{l}\text { Dikkate } \\
\text { alınmadı }\end{array}$ \\
\hline $\begin{array}{l}\text { Sarma } \\
\text { (2008: 5) }\end{array}$ & $\begin{array}{l}\text { Kredi, Ta- } \\
\text { sarruf }\end{array}$ & $\begin{array}{l}\text { * Demografik } \\
\text { Banka nüfuzu } \\
\text { (1000 yetişkin } \\
\text { başına Banka } \\
\text { hesabı sayısı) }\end{array}$ & $\begin{array}{l}\text { * Demografik } \\
\text { şube nüfuzu } \\
\text { (100.000 ye- } \\
\text { tişkin başına } \\
\text { Banka şubesi } \\
\text { sayısı) }\end{array}$ & $\begin{array}{l}\text { * Kredi göstergeleri: } \\
\text { i. Yurtiçi kre- } \\
\text { di (GSYiH'nın } \\
\text { yüzdesi olarak) } \\
\text { * Mevduat göster- } \\
\text { geleri: } \\
\text { ii. Yurtiçi mevduat } \\
\text { (GSYIH'nın yüzdesi } \\
\text { olarak) }\end{array}$ & $\begin{array}{l}\text { Dikkate } \\
\text { alınmadı }\end{array}$ & $\begin{array}{l}\text { Dikkate } \\
\text { alınmadı }\end{array}$ \\
\hline
\end{tabular}


Tablo 2'nin devamı

\begin{tabular}{|c|c|c|c|c|c|c|}
\hline \multirow{3}{*}{ Yazarlar } & \multirow{3}{*}{$\begin{array}{l}\text { Finansal } \\
\text { hizmetler }\end{array}$} & \multicolumn{5}{|c|}{ Boyutlar } \\
\hline & & \multicolumn{2}{|c|}{ Sosyal Yardım } & \multirow[b]{2}{*}{ Kullanım } & \multirow[b]{2}{*}{ Kolaylaş̧tırmak } & \multirow[b]{2}{*}{ Maliyet } \\
\hline & & Erişebilirlik & $\begin{array}{l}\text { Kullanılabi- } \\
\text { dirlik }\end{array}$ & & & \\
\hline $\begin{array}{l}\text { Mersland } \\
\& \text { Øystein } \\
\text { Strøm } \\
\text { (2009: 17) }\end{array}$ & Kredi & $\begin{array}{l}\text { * Ortalama } \\
\text { kredi miktarı } \\
\text { * Kredi kulla- } \\
\text { nan yetişkin } \\
\text { sayısı }\end{array}$ & $\begin{array}{l}\text { Dikkate } \\
\text { alınmadı }\end{array}$ & $\begin{array}{l}\text { Dikkate } \\
\text { alınmadı }\end{array}$ & Dikkate alınmadı & $\begin{array}{l}\text { Dikkate alın- } \\
\text { madı }\end{array}$ \\
\hline $\begin{array}{l}\text { Chakra- } \\
\text { varty \& Pal } \\
(2010: 12)\end{array}$ & $\begin{array}{l}\text { Kredi, } \\
\text { Tasarruf }\end{array}$ & \multicolumn{3}{|c|}{$\begin{array}{l}\text { Beck, Demirguc-Kunt ve Martinez Peria } \\
\text { (2005:44) ve Sarma (2008: } 5) \text { 'da belirti- } \\
\text { len boyut ve göstergeleri kullanmıştır. }\end{array}$} & Dikkate alınmadı & $\begin{array}{l}\text { Dikkate alın- } \\
\text { madı }\end{array}$ \\
\hline $\begin{array}{l}\text { Arora } \\
(2010: 5)\end{array}$ & $\begin{array}{l}\text { Kredi, } \\
\text { Tasarruf }\end{array}$ & $\begin{array}{l}\text { *Demografik } \\
\text { şube nüfuzu } \\
\text { (100.000 kişi } \\
\text { başına Banka } \\
\text { şubesi sayısı) } \\
\text { *Demografik } \\
\text { ATM nüfuzu } \\
\text { (100.000 kişi } \\
\text { başına Banka } \\
\text { ATM sayısı) }\end{array}$ & $\begin{array}{l}{ }^{*} \text { Coğrafi } \\
\text { nüfuz }(1.000 \\
\mathrm{m}^{2} \text { başına } \\
\text { Banka şu- } \\
\text { besi sayısı). } \\
{ }^{*} \text { Coğrafi } \\
\text { penetras- } \\
\text { yon (1.000 } \\
\text { metrekare } \\
\text { başına Banka } \\
\text { ATM sayısı) }\end{array}$ & $\begin{array}{l}\text { Dikkate } \\
\text { alınmadı }\end{array}$ & $\begin{array}{l}\text { *Mevduat hesabını } \\
\text { açacak yerler } \\
\text { *Hesap açmak için } \\
\text { minimum miktar } \\
\text { *Tasarruf hesabı } \\
\text { açmak için mini- } \\
\text { mum miktar } \\
\text { *Hesap kontrolün- } \\
\text { de tutulması gere- } \\
\text { ken asgari tutar } \\
\text { *Tasarruf hesabın- } \\
\text { da tutulacak asgari } \\
\text { tutar } \\
\text { *Hesap açmak için } \\
\text { belge sayısı } \\
\text { *Tasarruf hesabını } \\
\text { açmak için belge } \\
\text { sayısı } \\
\text { *Kredi başvuru- } \\
\text { larını gönderecek } \\
\text { yerler } \\
\text { *Minimum tüketici } \\
\text { kredisi miktarı } \\
\text { *Minimum ipotek } \\
\text { kredisi miktarı } \\
\text { *Tüketici kredisi } \\
\text { başvurusunu işle- } \\
\text { me koyma günleri } \\
\text { *ipotek kredisi } \\
\text { başvurusunu işle- } \\
\text { me koyma günleri }\end{array}$ & $\begin{array}{l}\text { *Tüketici } \\
\text { kredisi ücreti } \\
\text { (asgari kredi } \\
\text { tutarının\% 'si) } \\
\text { *Konut ipo- } \\
\text { teği kredisi } \\
\text { (asgari kredi } \\
\text { tutarının\% 'si) } \\
\text { *Yıllık tasarruf } \\
\text { hesabı ücreti } \\
\text { *Uluslararası } \\
\text { transfer fonla- } \\
\text { rının maliyeti } \\
\text { (250 \$ 'dan } \\
\text { yüzdesi) } \\
\text { *ATM kartları- } \\
\text { nı kullanmayla } \\
\text { ilgili ücret } \\
\text { tutarı (100 \$ } \\
\text { 'dan yüzdesi) }\end{array}$ \\
\hline
\end{tabular}

M. Gündüz, Y. Özyıldıım, "Finansal Kapsayıcılığın Gelişmesinde Katııım Bankacııı̆̆ının Rolü: Katııım Bankacilığı Finansal Kapsayıcılık Endeksinin Hesaplanması”, BDDK Bankacilık ve Finansal Piyasalar Dergisi, 14, (2), 2020, 119-144 
Tablo 2'nin devamı

\begin{tabular}{|c|c|c|c|c|c|c|}
\hline \multirow{3}{*}{ Yazarlar } & \multirow{3}{*}{$\begin{array}{l}\text { Finansal } \\
\text { hizmetler }\end{array}$} & \multicolumn{5}{|c|}{ Boyutlar } \\
\hline & & \multicolumn{2}{|c|}{ Sosyal Yardım } & \multirow{2}{*}{ Kullanım } & \multirow{2}{*}{ Kolaylaştırmak } & \multirow{2}{*}{ Maliyet } \\
\hline & & Erişebilirlik & Kullanılabilirlik & & & \\
\hline Prathap (2011) & $\begin{array}{l}\text { Bankacılık } \\
\text { İşlemleri, } \\
\text { Tasarruf, } \\
\text { Kredi ve } \\
\text { Sigorta }\end{array}$ & $\begin{array}{l}\text { Dikkate } \\
\text { alınmadı }\end{array}$ & $\begin{array}{l}\text { Dikkate alın- } \\
\text { madı }\end{array}$ & $\begin{array}{l}\text { * Bankacılık } \\
\text { işlemi: Bankalar } \\
\text { aracılığıyla çek, } \\
\text { sosyal güvenlik, } \\
\text { emeklilik ödeme- } \\
\text { lerinin kullanımı, } \\
\text { ATM kullanımı } \\
\text { * Tasarruflar: } \\
\text { Tasarruflar, ku- } \\
\text { rumsal kaynaklar- } \\
\text { la (ticari Banka, } \\
\text { kooperatif Banka- } \\
\text { Sı, postane veya } \\
\text { SHG14 Banka } \\
\text { bağlantısı), ku- } \\
\text { rumsal kaynaklar- } \\
\text { la sabit mevduat } \\
\text { veya tekrarlayan } \\
\text { mevduat hesa- } \\
\text { bıyla hesaplanır. } \\
\text { * Kredi: Kurumsal } \\
\text { kaynaklardan } \\
\text { veya } 2007,2008 \\
\text { ve } 2009 \text { yıllarında- } \\
\text { ki SHG Bankası / } \\
\text { MFP15 bağlantısı } \\
\text { yoluyla } \\
\text { * Sigorta: Herhan- } \\
\text { gi bir sigorta tipi } \\
\text { kaynak yoluyla }\end{array}$ & $\begin{array}{l}\text { Dikkate alın- } \\
\text { madı }\end{array}$ & $\begin{array}{l}\text { Dikkate } \\
\text { alınmadı }\end{array}$ \\
\hline $\begin{array}{l}\text { Gupte, Ven- } \\
\text { kataramani, \& } \\
\text { Gupta }(2012 \text { : } \\
\text { 138) }\end{array}$ & $\begin{array}{l}\text { Kredi, } \\
\text { Tasarruf }\end{array}$ & \multicolumn{5}{|c|}{$\begin{array}{l}\text { Hindistan için Finansal Kapsayıcılık Endeksi hesaplamak üzere Sarma (2008: } \\
\text { 5) ve Arora (2010: 5) tarafından oluşturulan dört boyutu entegre edip o } \\
\text { şekilde hesaplamıştır. }\end{array}$} \\
\hline
\end{tabular}

Dipnot: Öz yardım grupları (SHGs), kredi kullanım imkânlarını temin etmek için Hindistan Merkez Bankası adı altında yürütülen politikalardan biridir.

Mikrofinans Sağlayıcısı (MFP) yoksullara finansal yardımın bir parçası olarak SHGs finansman (kredi / hibe) sağlamak üzere tüm imkânları içermektedir.

Kaynak:Seman (2016, s. 62-64). Financial Inclusion: The Role of Financial System and Other Determinants 


\section{Finansal Kapsayıcılık Endeksi'nin (FKE) Oluşturulması}

\subsection{Yöntem}

Endeksin hesaplanmasında çok boyutlu bir yol izlenerek birden fazla değişkenden yararlanılır. Bu yol küresel anlamda birçok kişi tarafından bilinen Birleşmiş Milletler Geliştirme Programı (UNDP) tarafından oluşturulan İnsani Gelişmişlik Endeksi (HDI), Insani Yoksulluk Endeksi (HPI), Gayri Safi Milli Gelir (GDI) vb. endekslerin oluşumunda izlenen yöntem ile benzerlik göstermektedir (Sarma ve Pais, 2011: 615).

Öncelikle finansal kapsayıcılık endeksini meydana getiren her bir değişkenin endekste kullanılmak üzere boyut endeksleri hesaplanmaktadır. Her bir boyut endeksi

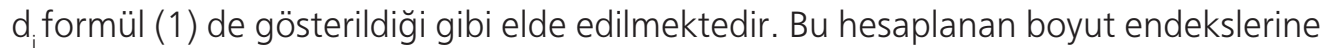
i. boyutuna bağlı olarak $0<$ wi < 1 arasında bir ağırlık verilir ve bu ağırlıklar her bir değişkenin finansal ürün ve hizmet sistemi içindeki önemlilik düzeyine göre belirlenmektedir. Ancak oluşturulan endekste her bir değişkenin önemi aynı olarak kabul edilmiş ve tüm boyutlara eşit ağırlıklandırma uygulanmıştır (Sarma, 2010:8).

$$
d_{i}=w_{i} \frac{A_{i}-m_{i}}{M_{i}-m_{i}}
$$

$A_{i}=$ Boyut i'nin düzey değeri.

$m_{i}=$ Boyut i'nin düzey değerinin alt sınırı

$M_{i}=$ Boyut i'nin düzey değerinin üst sınırı

$w_{i}=$ Boyut i'nin ağırlık değeri.

Her bir boyut değeri Formül (1) ile hesaplanarak $0 \leq d_{i} \leq w_{i}$ aralığında değerler haline getirilir. Finansal kapsayıcılığın hesaplandığı boyut değerleri n boyutlu uzayda $\mathrm{D}=\left(d_{1}, d_{2}, d_{3}, \ldots d_{n}\right)$ ifade edildiği gibi gösterilmektedir. Bu n boyutlu uzay gösteriminde $0=(0,0,0, \ldots 0)$ noktası en düşük finansal kapsayıcılık düzeyini gösterirken,1 $=(1,1,1, \ldots 1)$ noktası ise en yüksek finansal kapsayıcılık noktasını tanımlamaktadır. İdeal D noktasının $\mathrm{W}=\left(w_{1}, w_{2}, w_{3}, \ldots w_{n}\right)$ Öklid Uzaklığı Formül (2)'deki gibi Normalize Edilmiş Ters Öklid Uzaklığı ile ölçülmektedir (Sarma, 2010:8).

$$
F K E=1-\frac{\sqrt{\left(w_{1}-d_{1}\right)^{2}+\left(w_{2}-d_{2}\right)^{2}+\ldots+\left(w_{n}-d_{n}\right)^{2}}}{\sqrt{\left(w_{1}^{2}+w_{2}^{2}+\ldots+w_{n}^{2}\right)}}
$$

Formül (2) de gösterilen D noktasının ideal noktadan uzaklığını ölçmek için, atanan her bir ağırlıktan çıkartılıp n kadar atanan ağırlığın toplamına oranlanmasıyla normalize edilmiş uzaklık elde edilir. Bu sayede normalize edilmiş uzaklık 1'den çıkartılarak ters normalize edilmiş uzaklık hesaplanmış olunur.Böylece hesaplanan

M. Gündüz, Y. Özyıldııım, “Finansal Kapsayıcııı̆ın Gelişmesinde Katıım Bankacılığının Rolü: Katııım Bankacılığı Finansal Kapsayıcılık Endeksinin Hesaplanması”, BDDK Bankacilık ve Finansal Piyasalar Dergisi, 14, (2), 2020, 119-144 
finansal kapsayıcılık endeks değerleri 0 ile 1 aralığında değerlere dönüştürülür. Her boyut için eşit ağırlıklandırma uygulandığı için $w_{i}=1$ olur ve $\mathrm{n}$ boyutlu uzayda $w_{i}$ $=(1,1,1, \ldots 1)$ noktası ile gösterilip FKE için elde edilecek formül 3. aşamadaki gibi olacaktır (Sarma, 2008:5).

$$
F K E=1-\frac{\sqrt{\left(1-d_{1}\right)^{2}+\left(1-d_{2}\right)^{2}+\ldots+\left(1-d_{n}\right)^{2}}}{\sqrt{n}}
$$

Tablo 3'de gösterilenfinansal kapsayıcılık boyutunun sınıflandırılmış hali düşük, orta ve yüksek şeklinde gruplardan oluşmaktadır. Dolayısıyla yapılan sınıflandırma gerek iller gerekse de hesaplanacak farklı endeks birimleri arasında karşılaştırma yapılmasına imkân tanımaktadır.

\section{Tablo 3. Sınıflandırılmış FKE Değerleri}

\begin{tabular}{|c|c|c|c|c|c|c|c|}
\hline 1 & 0.000 & $\leq$ & FKE & $<$ & 0.300 & - & Düşük \\
\hline 2 & 0.300 & $\leq$ & FKE & $<$ & 0.500 & - & Orta \\
\hline 3 & 0.500 & $\leq$ & FKE & $\leq$ & Üstü & - & Yüksek \\
\hline
\end{tabular}

Kaynak: Sarma (2008: 5), Finansal Kapsayıcılık Endeksi

Yukarıda belirtilen yöntem neticesinde oluşturulan Katılım Bankacılığının FKE değerleri 2007 yılından başlayarak 2019 yılına kadar Tablo 4'de iller bazında hesaplanmıştır. Devamında endeks hesaplanmasında yer alan değerlerin boyutları detaylı şekilde 2019 yılı için Tablo 5'de gösterilmiştir.

\subsection{Veri}

Türkiye'nin 81 ili için elde edilen verilerin 2007 yılında başlayarak 2019 yılına kadar devam etmesi sebebiyle bu yılları kapsayan Katılım Bankacılığının Finansal Kapsayıcılık Endeksi hesaplanmıştır. Hesaplama aşamasında kullanılan veriler BDDK (FinTürk illere göre bankacılık verileri) ve TÜí'in bölgesel veri tabanı altında yer alan adrese dayalı nüfus kayıt sisteminden alınmıştır.TÜIK'den alınan veriler nüfus verileridir. Nakdi kredi miktarı ve tasarruf mevduatı miktarı BDDK'dan elde edilmiştir. Bu şekilde boyut endeksleri ve Katılım Bankacılığının FKE oluşturulmuştur. Endeks hesaplamasında ATM ve hesap sayılarına erişim mevduat bankacılığı için mevcutken katılım bankacılığı için bu verilere ulaşmak mümkün olmamıştır. Bu nedenle ATM ve hesap sayılarına ilişkin veriler endeksin hesaplanmasında kullanılamamıştır. 
Tablo 4.Türkiye'deki 81 ì İçin KBFKE Değerleri (Yüzde Olarak)

\begin{tabular}{|c|c|c|c|c|c|c|c|c|c|c|c|c|c|}
\hline Şehir & 2007 & 2008 & 2009 & 2010 & 2011 & 2012 & 2013 & 2014 & 2015 & 2016 & 2017 & 2018 & 2019 \\
\hline ADANA & 0.078 & 0.220 & 0.221 & 0.229 & 0.226 & 0.232 & 0.240 & 0.244 & 0.240 & 0.243 & 0.335 & 0.221 & 0.341 \\
\hline ADIYAMAN & 0.228 & 0.103 & 0.136 & 0.156 & 0.150 & 0.164 & 0.164 & 0.159 & 0.149 & 0.138 & 0.243 & 0.128 & 0.259 \\
\hline AFYONKARAHISAR & 0.000 & 0.202 & 0.199 & 0.209 & 0.208 & 0.218 & 0.208 & 0.203 & 0.193 & 0.182 & 0.327 & 0.211 & 0.301 \\
\hline AĞRI & 0.224 & 0.000 & 0.000 & 0.003 & 0.038 & 0.038 & 0.065 & 0.062 & 0.064 & 0.051 & 0.175 & 0.064 & 0.187 \\
\hline AKSARAY & 0.000 & 0.276 & 0.294 & 0.282 & 0.280 & 0.295 & 0.284 & 0.286 & 0.341 & 0.355 & 0.445 & 0.343 & 0.407 \\
\hline AMASYA & 0.414 & 0.063 & 0.069 & 0.151 & 0.154 & 0.154 & 0.153 & 0.154 & 0.194 & 0.183 & 0.276 & 0.150 & 0.266 \\
\hline ANKARA & 0.272 & 0.417 & 0.418 & 0.475 & 0.475 & 0.466 & 0.461 & 0.447 & 0.432 & 0.453 & 0.524 & 0.474 & 0.554 \\
\hline ANTALYA & 0.000 & 0.274 & 0.282 & 0.304 & 0.307 & 0.309 & 0.304 & 0.272 & 0.268 & 0.242 & 0.332 & 0.223 & 0.335 \\
\hline ARDAHAN & 0.000 & 0.000 & 0.000 & 0.005 & 0.007 & 0.005 & 0.007 & 0.004 & 0.003 & 0.007 & 0.142 & 0.015 & 0.145 \\
\hline ARTVIN & 0.099 & 0.000 & 0.000 & 0.010 & 0.006 & 0.008 & 0.005 & 0.007 & 0.005 & 0.009 & 0.140 & 0.004 & 0.136 \\
\hline AYDIN & 0.111 & 0.103 & 0.157 & 0.176 & 0.163 & 0.147 & 0.147 & 0.173 & 0.151 & 0.157 & 0.266 & 0.156 & 0.275 \\
\hline BALIKESIR & 0.000 & 0.115 & 0.114 & 0.138 & 0.150 & 0.152 & 0.161 & 0.172 & 0.157 & 0.143 & 0.279 & 0.173 & 0.278 \\
\hline BARTIN & 0.294 & 0.000 & 0.000 & 0.020 & 0.116 & 0.183 & 0.186 & 0.188 & 0.173 & 0.123 & 0.242 & 0.112 & 0.232 \\
\hline BATMAN & 0.000 & 0.279 & 0.310 & 0.324 & 0.311 & 0.335 & 0.345 & 0.295 & 0.269 & 0.256 & 0.349 & 0.239 & 0.336 \\
\hline BAYBURT & 0.000 & 0.000 & 0.000 & 0.050 & 0.033 & 0.016 & 0.059 & 0.113 & 0.056 & 0.037 & 0.159 & 0.027 & 0.158 \\
\hline BILECIK & 0.000 & 0.000 & 0.000 & 0.021 & 0.018 & 0.163 & 0.159 & 0.172 & 0.160 & 0.114 & 0.229 & 0.104 & 0.216 \\
\hline BINGÖL & 0.000 & 0.084 & 0.096 & 0.105 & 0.102 & 0.101 & 0.131 & 0.143 & 0.141 & 0.142 & 0.259 & 0.144 & 0.259 \\
\hline BiTLIS & 0.191 & 0.000 & 0.000 & 0.004 & 0.092 & 0.095 & 0.099 & 0.134 & 0.127 & 0.098 & 0.225 & 0.094 & 0.183 \\
\hline BOLU & 0.000 & 0.240 & 0.231 & 0.364 & 0.363 & 0.393 & 0.345 & 0.349 & 0.350 & 0.302 & 0.375 & 0.257 & 0.377 \\
\hline BURDUR & 0.355 & 0.000 & 0.083 & 0.113 & 0.103 & 0.092 & 0.095 & 0.145 & 0.177 & 0.196 & 0.303 & 0.179 & 0.248 \\
\hline BURSA & 0.000 & 0.343 & 0.331 & 0.351 & 0.346 & 0.362 & 0.388 & 0.388 & 0.381 & 0.400 & 0.468 & 0.390 & 0.486 \\
\hline ÇANAKKALE & 0.000 & 0.085 & 0.107 & 0.144 & 0.135 & 0.168 & 0.176 & 0.144 & 0.145 & 0.109 & 0.222 & 0.108 & 0.224 \\
\hline ÇANKIRI & 0.181 & 0.000 & 0.000 & 0.069 & 0.154 & 0.142 & 0.191 & 0.202 & 0.224 & 0.264 & 0.387 & 0.210 & 0.299 \\
\hline ÇORUM & 0.329 & 0.172 & 0.182 & 0.188 & 0.174 & 0.185 & 0.170 & 0.166 & 0.195 & 0.195 & 0.319 & 0.206 & 0.303 \\
\hline DENIZLI & 0.161 & 0.269 & 0.278 & 0.282 & 0.258 & 0.254 & 0.272 & 0.282 & 0.295 & 0.293 & 0.393 & 0.289 & 0.365 \\
\hline DIYARBAKIR & 0.260 & 0.158 & 0.160 & 0.174 & 0.167 & 0.164 & 0.174 & 0.169 & 0.171 & 0.173 & 0.287 & 0.161 & 0.282 \\
\hline DÜZCE & 0.059 & 0.337 & 0.344 & 0.400 & 0.378 & 0.350 & 0.380 & 0.373 & 0.366 & 0.329 & 0.397 & 0.311 & 0.411 \\
\hline EDIRNE & 0.273 & 0.066 & 0.067 & 0.127 & 0.140 & 0.127 & 0.118 & 0.100 & 0.116 & 0.121 & 0.234 & 0.105 & 0.238 \\
\hline ELAZIĞ & 0.181 & 0.244 & 0.253 & 0.263 & 0.265 & 0.235 & 0.215 & 0.230 & 0.255 & 0.265 & 0.407 & 0.313 & 0.385 \\
\hline ERZINCAN & 0.165 & 0.175 & 0.175 & 0.313 & 0.359 & 0.355 & 0.336 & 0.360 & 0.345 & 0.303 & 0.456 & 0.379 & 0.464 \\
\hline ERZURUM & 0.305 & 0.172 & 0.178 & 0.206 & 0.201 & 0.184 & 0.176 & 0.178 & 0.179 & 0.193 & 0.315 & 0.190 & 0.288 \\
\hline ESKIŞEHIR & 0.314 & 0.251 & 0.249 & 0.253 & 0.259 & 0.256 & 0.242 & 0.226 & 0.205 & 0.210 & 0.331 & 0.208 & 0.326 \\
\hline GAZIANTEP & 0.000 & 0.276 & 0.259 & 0.286 & 0.294 & 0.297 & 0.306 & 0.305 & 0.298 & 0.304 & 0.409 & 0.335 & 0.439 \\
\hline GIRESUN & 0.000 & 0.056 & 0.063 & 0.074 & 0.149 & 0.176 & 0.172 & 0.181 & 0.175 & 0.167 & 0.267 & 0.136 & 0.247 \\
\hline GÜMÜŞHANE & 0.000 & 0.000 & 0.000 & 0.020 & 0.016 & 0.028 & 0.118 & 0.126 & 0.124 & 0.125 & 0.240 & 0.132 & 0.254 \\
\hline HAKKẨRI & 0.113 & 0.000 & 0.000 & 0.002 & 0.002 & 0.001 & 0.000 & 0.000 & 0.002 & 0.003 & 0.137 & 0.002 & 0.134 \\
\hline HATAY & 0.000 & 0.130 & 0.146 & 0.167 & 0.166 & 0.153 & 0.169 & 0.150 & 0.171 & 0.171 & 0.284 & 0.169 & 0.288 \\
\hline IĞDIR & 0.312 & 0.000 & 0.000 & 0.002 & 0.000 & 0.001 & 0.001 & 0.003 & 0.000 & 0.000 & 0.134 & 0.001 & 0.184 \\
\hline ISPARTA & 1.000 & 0.324 & 0.333 & 0.325 & 0.332 & 0.325 & 0.308 & 0.336 & 0.328 & 0.313 & 0.423 & 0.319 & 0.393 \\
\hline ISTANBUL & 0.219 & 1.000 & 1.000 & 1.000 & 1.000 & 1.000 & 1.000 & 1.000 & 1.000 & 1.000 & 1.000 & 1.000 & 1.000 \\
\hline izMiR & 0.198 & 0.214 & 0.227 & 0.241 & 0.257 & 0.266 & 0.277 & 0.241 & 0.213 & 0.201 & 0.312 & 0.206 & 0.325 \\
\hline KAHRAMANMARAŞ & 0.142 & 0.177 & 0.169 & 0.177 & 0.163 & 0.177 & 0.180 & 0.212 & 0.205 & 0.252 & 0.356 & 0.246 & 0.337 \\
\hline KARABÜK & 0.188 & 0.217 & 0.265 & 0.453 & 0.401 & 0.368 & 0.342 & 0.364 & 0.363 & 0.344 & 0.443 & 0.308 & 0.396 \\
\hline KARAMAN & 0.000 & 0.172 & 0.173 & 0.263 & 0.280 & 0.335 & 0.346 & 0.359 & 0.384 & 0.375 & 0.444 & 0.405 & 0.468 \\
\hline KARS & 0.066 & 0.000 & 0.000 & 0.002 & 0.060 & 0.060 & 0.060 & 0.065 & 0.062 & 0.068 & 0.196 & 0.059 & 0.217 \\
\hline KASTAMONU & 0.481 & 0.120 & 0.141 & 0.186 & 0.194 & 0.187 & 0.197 & 0.204 & 0.190 & 0.168 & 0.294 & 0.169 & 0.280 \\
\hline KAYSERI & 0.121 & 0.414 & 0.372 & 0.395 & 0.374 & 0.383 & 0.400 & 0.400 & 0.395 & 0.410 & 0.500 & 0.402 & 0.476 \\
\hline KIRIKKALE & 0.000 & 0.174 & 0.195 & 0.207 & 0.194 & 0.237 & 0.231 & 0.232 & 0.231 & 0.194 & 0.287 & 0.165 & 0.270 \\
\hline KIRKLARELI & 0.130 & 0.060 & 0.065 & 0.077 & 0.086 & 0.113 & 0.085 & 0.105 & 0.084 & 0.079 & 0.192 & 0.058 & 0.192 \\
\hline KIRŞEHIR & 0.000 & 0.115 & 0.122 & 0.126 & 0.134 & 0.180 & 0.230 & 0.231 & 0.218 & 0.189 & 0.329 & 0.268 & 0.357 \\
\hline KiLis & 0.464 & 0.000 & 0.000 & 0.013 & 0.010 & 0.012 & 0.026 & 0.025 & 0.022 & 0.022 & 0.150 & 0.027 & 0.237 \\
\hline KOCAELI & 0.460 & 0.404 & 0.434 & 0.442 & 0.444 & 0.420 & 0.452 & 0.439 & 0.420 & 0.442 & 0.504 & 0.445 & 0.494 \\
\hline KONYA & 0.178 & 0.421 & 0.397 & 0.438 & 0.440 & 0.445 & 0.450 & 0.449 & 0.473 & 0.496 & 0.569 & 0.473 & 0.513 \\
\hline KÜTAHYA & 0.239 & 0.168 & 0.173 & 0.195 & 0.192 & 0.194 & 0.216 & 0.219 & 0.203 & 0.195 & 0.300 & 0.195 & 0.299 \\
\hline MALATYA & 0.125 & 0.236 & 0.228 & 0.249 & 0.249 & 0.239 & 0.242 & 0.233 & 0.213 & 0.200 & 0.331 & 0.218 & 0.325 \\
\hline MANISA & 0.000 & 0.117 & 0.148 & 0.170 & 0.165 & 0.155 & 0.193 & 0.195 & 0.193 & 0.166 & 0.282 & 0.163 & 0.267 \\
\hline MARDIN & 0.146 & 0.032 & 0.061 & 0.072 & 0.072 & 0.071 & 0.108 & 0.130 & 0.121 & 0.115 & 0.229 & 0.104 & 0.215 \\
\hline MERSIN & 0.000 & 0.126 & 0.131 & 0.142 & 0.143 & 0.156 & 0.155 & 0.168 & 0.178 & 0.190 & 0.306 & 0.213 & 0.334 \\
\hline MUĞLA & 0.000 & 0.000 & 0.028 & 0.056 & 0.076 & 0.072 & 0.099 & 0.114 & 0.106 & 0.098 & 0.219 & 0.096 & 0.202 \\
\hline MUŞ & 0.205 & 0.000 & 0.000 & 0.003 & 0.004 & 0.040 & 0.044 & 0.067 & 0.063 & 0.042 & 0.172 & 0.036 & 0.186 \\
\hline NEVŞEHIR & 0.000 & 0.192 & 0.214 & 0.232 & 0.246 & 0.233 & 0.307 & 0.326 & 0.316 & 0.303 & 0.392 & 0.314 & 0.403 \\
\hline NiĞDE & 0.089 & 0.000 & 0.000 & 0.026 & 0.134 & 0.128 & 0.124 & 0.157 & 0.157 & 0.126 & 0.232 & 0.110 & 0.231 \\
\hline ORDU & 0.213 & 0.114 & 0.129 & 0.168 & 0.167 & 0.190 & 0.186 & 0.221 & 0.208 & 0.189 & 0.287 & 0.187 & 0.291 \\
\hline OSMANIYE & 0.344 & 0.190 & 0.195 & 0.203 & 0.234 & 0.222 & 0.202 & 0.197 & 0.179 & 0.153 & 0.263 & 0.148 & 0.255 \\
\hline RiZE & 0.384 & 0.324 & 0.354 & 0.408 & 0.376 & 0.334 & 0.325 & 0.330 & 0.319 & 0.376 & 0.524 & 0.458 & 0.505 \\
\hline SAKARYA & 0.185 & 0.366 & 0.327 & 0.296 & 0.283 & 0.243 & 0.238 & 0.230 & 0.235 & 0.260 & 0.377 & 0.259 & 0.340 \\
\hline SAMSUN & 0.122 & 0.175 & 0.168 & 0.166 & 0.159 & 0.183 & 0.199 & 0.193 & 0.186 & 0.187 & 0.297 & 0.178 & 0.290 \\
\hline SiliRT & 0.000 & 0.123 & 0.126 & 0.265 & 0.229 & 0.185 & 0.214 & 0.249 & 0.242 & 0.224 & 0.378 & 0.398 & 0.467 \\
\hline SINOP & 0.281 & 0.000 & 0.000 & 0.012 & 0.015 & 0.017 & 0.075 & 0.072 & 0.064 & 0.012 & 0.143 & 0.010 & 0.145 \\
\hline SIVAS & 0.136 & 0.260 & 0.258 & 0.267 & 0.270 & 0.297 & 0.299 & 0.306 & 0.296 & 0.299 & 0.408 & 0.297 & 0.361 \\
\hline ŞANLIURFA & 0.000 & 0.112 & 0.112 & 0.121 & 0.119 & 0.134 & 0.125 & 0.124 & 0.125 & 0.134 & 0.250 & 0.124 & 0.239 \\
\hline ŞIRNAK & 0.131 & 0.000 & 0.000 & 0.001 & 0.001 & 0.001 & 0.055 & 0.056 & 0.053 & 0.047 & 0.170 & 0.036 & 0.168 \\
\hline TEKIRDAĞ & 0.041 & 0.223 & 0.268 & 0.270 & 0.269 & 0.274 & 0.246 & 0.243 & 0.225 & 0.189 & 0.286 & 0.173 & 0.285 \\
\hline TOKAT & 0.359 & 0.108 & 0.123 & 0.136 & 0.139 & 0.126 & 0.134 & 0.131 & 0.125 & 0.114 & 0.227 & 0.100 & 0.217 \\
\hline TRABZON & 0.000 & 0.299 & 0.279 & 0.280 & 0.274 & 0.303 & 0.342 & 0.348 & 0.350 & 0.359 & 0.458 & 0.350 & 0.426 \\
\hline TUNCELI & 0.244 & 0.000 & 0.000 & 0.008 & 0.011 & 0.008 & 0.009 & 0.006 & 0.006 & 0.006 & 0.142 & 0.008 & 0.142 \\
\hline UŞAK & 0.107 & 0.285 & 0.300 & 0.319 & 0.323 & 0.285 & 0.262 & 0.253 & 0.272 & 0.251 & 0.377 & 0.276 & 0.365 \\
\hline VAN & 0.353 & 0.120 & 0.119 & 0.122 & 0.119 & 0.110 & 0.117 & 0.117 & 0.109 & 0.117 & 0.242 & 0.113 & 0.229 \\
\hline YALOVA & 0.000 & 0.367 & 0.420 & 0.420 & 0.406 & 0.405 & 0.440 & 0.490 & 0.435 & 0.393 & 0.488 & 0.385 & 0.457 \\
\hline YOZGAT & 0.173 & 0.046 & 0.050 & 0.075 & 0.073 & 0.111 & 0.112 & 0.101 & 0.125 & 0.111 & 0.256 & 0.132 & 0.244 \\
\hline ZONGULDAK & 0.000 & 0.156 & 0.154 & 0.156 & 0.168 & 0.179 & 0.170 & 0.174 & 0.167 & 0.129 & 0.242 & 0.110 & 0.274 \\
\hline
\end{tabular}

Kaynak: BDDK ve TÜiK' ten elde edilen veriler kullanılarak yazarlar tarafından hesaplanmıştır. 
Tablo 5.Türkiye'deki 81 İlin 2019 Yılı İçin KBFKE'nin Boyut Değerleri

\begin{tabular}{|c|c|c|c|c|c|c|c|c|}
\hline \multirow{2}{*}{ Şehir } & \multicolumn{2}{|c|}{ 100.000 Kişi Başına Şube Sayısı } & \multicolumn{2}{|c|}{ Kişi Başı Nakdi Kredi } & Kişi Başı Ta & Tevduatı & & \\
\hline & d1 & Sira & $d 2$ & Sira & d3 & Sira & Yüzde & Sira \\
\hline ADANA & 0.344 & 30 & 0.223 & 17 & 0.162 & 38 & 0.341 & 25 \\
\hline ADIYAMAN & 0.267 & 46 & 0.045 & 62 & 0.135 & 43 & 0.259 & 52 \\
\hline AFYONKARAHISAR & 0.275 & 45 & 0.109 & 36 & 0.204 & 28 & 0.301 & 35 \\
\hline AĞRI & 0.125 & 72 & 0.014 & 73 & 0.048 & 71 & 0.187 & 71 \\
\hline AKSARAY & 0.402 & 18 & 0.114 & 33 & 0.490 & 3 & 0.407 & 15 \\
\hline AMASYA & 0.297 & 41 & 0.082 & 44 & 0.096 & 59 & 0.266 & 50 \\
\hline ANKARA & 0.534 & 8 & 0.611 & 2 & 0.346 & 10 & 0.554 & 2 \\
\hline ANTALYA & 0.399 & 19 & 0.155 & 22 & 0.168 & 37 & 0.335 & 29 \\
\hline ARDAHAN & 0.000 & 76 & 0.029 & 66 & 0.009 & 78 & 0.145 & 77 \\
\hline ARTVIN & 0.000 & 77 & 0.002 & 80 & 0.006 & 80 & 0.136 & 80 \\
\hline AYDIN & 0.331 & 32 & 0.090 & 40 & 0.091 & 62 & 0.275 & 46 \\
\hline BALIKESIR & 0.299 & 40 & 0.102 & 38 & 0.113 & 53 & 0.278 & 45 \\
\hline BARTIN & 0.169 & 65 & 0.079 & 47 & 0.095 & 60 & 0.232 & 61 \\
\hline BATMAN & 0.330 & 33 & 0.115 & 32 & 0.272 & 19 & 0.336 & 28 \\
\hline BAYBURT & 0.000 & 78 & 0.010 & 75 & 0.074 & 65 & 0.158 & 76 \\
\hline BILECIK & 0.152 & 70 & 0.063 & 55 & 0.072 & 66 & 0.216 & 67 \\
\hline BINGÖL & 0.239 & 53 & 0.026 & 70 & 0.184 & 33 & 0.259 & 51 \\
\hline BitLis & 0.096 & 73 & 0.027 & 68 & 0.049 & 70 & 0.183 & 74 \\
\hline BOLU & 0.423 & 14 & 0.228 & 16 & 0.211 & 27 & 0.377 & 20 \\
\hline BURDUR & 0.247 & 49 & 0.064 & 54 & 0.097 & 58 & 0.248 & 55 \\
\hline BURSA & 0.591 & 5 & 0.341 & 8 & 0.324 & 13 & 0.486 & 6 \\
\hline CANAKKALE & 0.247 & 50 & 0.026 & 71 & 0.057 & 68 & 0.224 & 64 \\
\hline ÇANKIRI & 0.342 & 31 & 0.061 & 57 & 0.194 & 30 & 0.299 & 36 \\
\hline CORUM & 0.315 & 38 & 0.156 & 21 & 0.128 & 45 & 0.303 & 34 \\
\hline DENIZLI & 0.322 & 36 & 0.291 & 11 & 0.192 & 31 & 0.365 & 22 \\
\hline DIYARBAKIR & 0.248 & 48 & 0.103 & 37 & 0.169 & 36 & 0.282 & 43 \\
\hline DÜZCE & 0.426 & 13 & 0.265 & 13 & 0.280 & 17 & 0.411 & 14 \\
\hline EDIRNE & 0.242 & 52 & 0.072 & 49 & 0.058 & 67 & 0.238 & 59 \\
\hline ELAZIĞ & 0.396 & 20 & 0.232 & 15 & 0.253 & 21 & 0.385 & 19 \\
\hline ERZINCAN & 0.712 & 2 & 0.109 & 34 & 0.479 & 4 & 0.464 & 10 \\
\hline ERZURUM & 0.307 & 39 & 0.090 & 41 & 0.153 & 41 & 0.288 & 40 \\
\hline ESKIŞEHIR & 0.377 & 21 & 0.098 & 39 & 0.217 & 26 & 0.326 & 31 \\
\hline GAZIANTEP & 0.404 & 16 & 0.412 & 5 & 0.254 & 20 & 0.439 & 12 \\
\hline GIRESUN & 0.224 & 60 & 0.065 & 51 & 0.112 & 55 & 0.247 & 56 \\
\hline GÜMÜŞHANE & 0.203 & 61 & 0.062 & 56 & 0.156 & 39 & 0.254 & 54 \\
\hline HAKKÂRI & 0.000 & 79 & 0.000 & 81 & 0.000 & 81 & 0.134 & 81 \\
\hline HATAY & 0.246 & 51 & 0.116 & 31 & 0.176 & 34 & 0.288 & 41 \\
\hline IǦDIR & 0.168 & 66 & 0.006 & 78 & 0.008 & 79 & 0.184 & 73 \\
\hline ISPARTA & 0.376 & 22 & 0.128 & 30 & 0.432 & 7 & 0.393 & 18 \\
\hline ISTANBUL & 1.000 & 1 & 1.000 & 1 & 1.000 & 1 & 1.000 & 1 \\
\hline IZMiR & 0.329 & 34 & 0.223 & 18 & 0.123 & 48 & 0.325 & 32 \\
\hline KAHRAMANMARAS & 0.232 & 58 & 0.310 & 10 & 0.169 & 35 & 0.337 & 27 \\
\hline KARABÜK & 0.404 & 17 & 0.238 & 14 & 0.278 & 18 & 0.396 & 17 \\
\hline KARAMAN & 0.660 & 3 & 0.142 & 26 & 0.472 & 5 & 0.468 & 8 \\
\hline KARS & 0.234 & 57 & 0.026 & 69 & 0.042 & 72 & 0.217 & 66 \\
\hline KASTAMONU & 0.353 & 26 & 0.069 & 50 & 0.113 & 54 & 0.280 & 44 \\
\hline KAYSERI & 0.547 & 7 & 0.287 & 12 & 0.380 & 8 & 0.476 & 7 \\
\hline KIRIKKALE & 0.236 & 55 & 0.056 & 58 & 0.187 & 32 & 0.270 & 48 \\
\hline KIRKLARELI & 0.092 & 74 & 0.078 & 48 & 0.032 & 74 & 0.192 & 70 \\
\hline KIRŞEHIR & 0.275 & 44 & 0.376 & 6 & 0.141 & 42 & 0.357 & 24 \\
\hline KILIS & 0.235 & 56 & 0.013 & 74 & 0.122 & 49 & 0.237 & 60 \\
\hline KOCAELI & 0.617 & 4 & 0.361 & 7 & 0.316 & 14 & 0.494 & 5 \\
\hline KONYA & 0.569 & 6 & 0.314 & 9 & 0.459 & 6 & 0.513 & 3 \\
\hline KÜTAHYA & 0.346 & 28 & 0.053 & 59 & 0.198 & 29 & 0.299 & 37 \\
\hline MALATYA & 0.293 & 42 & 0.135 & 28 & 0.241 & 23 & 0.325 & 33 \\
\hline MANISA & 0.279 & 43 & 0.088 & 43 & 0.107 & 56 & 0.267 & 49 \\
\hline MARDIN & 0.160 & 69 & 0.040 & 64 & 0.083 & 64 & 0.215 & 68 \\
\hline MERSIN & 0.345 & 29 & 0.129 & 29 & 0.234 & 24 & 0.334 & 30 \\
\hline MUǦLA & 0.136 & 71 & 0.050 & 61 & 0.050 & 69 & 0.202 & 69 \\
\hline MUș & 0.164 & 68 & 0.004 & 79 & 0.020 & 77 & 0.186 & 72 \\
\hline NEVŞEHIR & 0.442 & 12 & 0.219 & 19 & 0.290 & 16 & 0.403 & 16 \\
\hline NiǦDE & 0.184 & 62 & 0.052 & 60 & 0.106 & 57 & 0.231 & 62 \\
\hline ORDU & 0.355 & 25 & 0.081 & 45 & 0.134 & 44 & 0.291 & 38 \\
\hline OSMANIYE & 0.248 & 47 & 0.065 & 52 & 0.115 & 52 & 0.255 & 53 \\
\hline RizE & 0.487 & 11 & 0.487 & 4 & 0.326 & 12 & 0.505 & 4 \\
\hline SAKARYA & 0.325 & 35 & 0.149 & 23 & 0.250 & 22 & 0.340 & 26 \\
\hline SAMSUN & 0.322 & 37 & 0.081 & 46 & 0.154 & 40 & 0.290 & 39 \\
\hline SiiRT & 0.405 & 15 & 0.585 & 3 & 0.219 & 25 & 0.467 & 9 \\
\hline SINOP & 0.000 & 80 & 0.009 & 76 & 0.029 & 75 & 0.145 & 78 \\
\hline SIVAS & 0.366 & 23 & 0.088 & 42 & 0.365 & 9 & 0.361 & 23 \\
\hline ŞANLIURFA & 0.177 & 63 & 0.064 & 53 & 0.128 & 46 & 0.239 & 58 \\
\hline ŞIRNAK & 0.063 & 75 & 0.021 & 72 & 0.033 & 73 & 0.168 & 75 \\
\hline TEKIRDAĞ & 0.349 & 27 & 0.109 & 35 & 0.092 & 61 & 0.285 & 42 \\
\hline TOKAT & 0.164 & 67 & 0.042 & 63 & 0.086 & 63 & 0.217 & 65 \\
\hline TRABZON & 0.496 & 9 & 0.209 & 20 & 0.337 & 11 & 0.426 & 13 \\
\hline TUNCELI & 0.000 & 81 & 0.008 & 77 & 0.020 & 76 & 0.142 & 79 \\
\hline UŞAK & 0.361 & 24 & 0.146 & 24 & 0.309 & 15 & 0.365 & 21 \\
\hline VAN & 0.177 & 64 & 0.037 & 65 & 0.120 & 50 & 0.229 & 63 \\
\hline YALOVA & 0.494 & 10 & 0.141 & 27 & 0.568 & 2 & 0.457 & 11 \\
\hline YOZGAT & 0.238 & 54 & 0.029 & 67 & 0.128 & 47 & 0.244 & 57 \\
\hline ZONGULDAK & 0.224 & 59 & 0.144 & 25 & 0.119 & 51 & 0.274 & 47 \\
\hline
\end{tabular}

Kaynak: BDDK ve TÜiK' ten elde edilen veriler kullanılarak yazarlar tarafından hesaplanmıştır. 
Bu değerlerden yola çıkarak Türkiye'deki Katılım Bankacılığının gelmiş olduğu nokta harita üzerinde değerlendirilmiştir. Harita 1'e bakıldığında Katılım Bankacılık hizmetlerini sunan Katılım Bankacılığı şube sayılarının iller arasında büyük farklııklar olduğu ve 8 ilde (Kilis, Kırklareli, Sinop, Hakkâri, Tunceli, Bayburt, Artvin ve Ardahan) Katılım Bankacılığı faaliyetlerini yürüten şubelerin bulunmadığı görülmektedir(PBAT, 2019). Ancak Kilis ve Kırklareli'nde şube hizmeti sağlanmasa da kamu bankaları aracılığıyla pencere hizmeti sağlanarak katılım bankacılığı hizmetleri kısmen de olsa sağlandığı söylenebilir. İllerin şube sayılarının nüfusa oranlanmasıyla elde edilen erişim boyutunda bulgular kişi başına düşen şube miktarını ifade etmektedir. Şubelere ulaşabilen kesimin bir şubeye düşen kişi sayısı nasıl bir hizmet aldığının göstergesidir.

\section{Harita 1. Türkiye'de 2019 Yılı İçin Katılım Bankacılığına Ait Şube Sayıları}

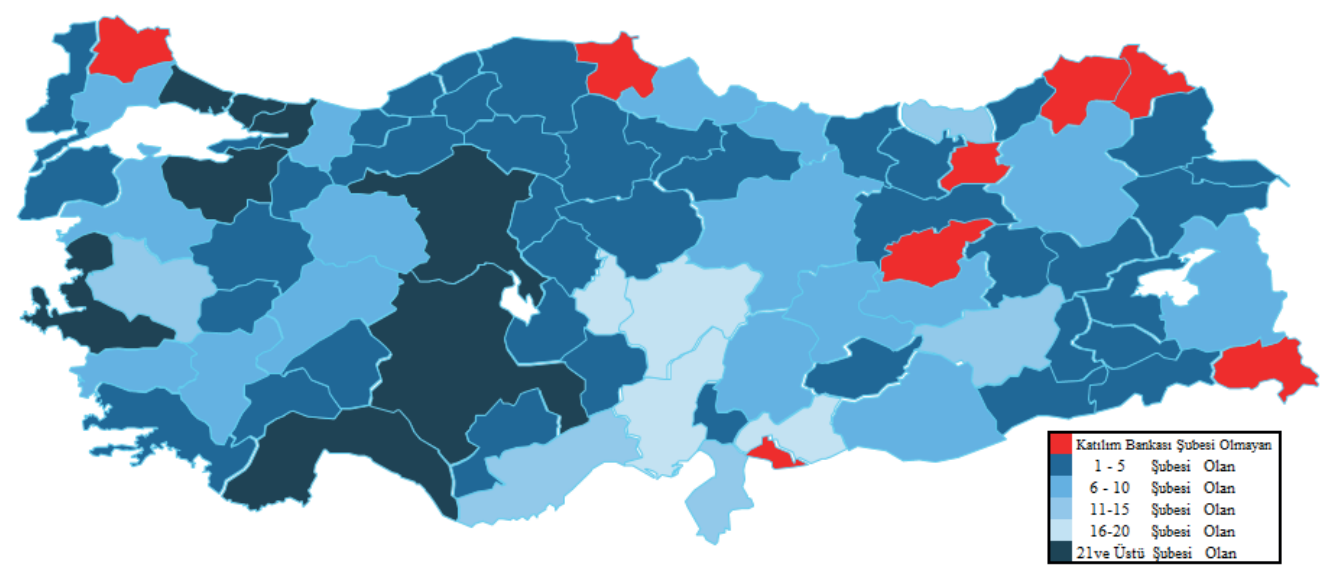

Harita 1'e bakıldığında büyük şehir ve büyük şehir statüsünde bulunan illerde Katılım Bankacılığının yaygınlaştığı saptanmıştır. Türkiye'de genel anlamda birçok ilin ise (İç Anadolu Bölgesi'nin orta kesimleriyle Karadeniz Bölgesi'nin batı kesimleri ve Güney Doğu Anadolu Bölgesi'nin büyük bir kısmı) 1-5 arası şube sayısına sahip olduğu görülmektedir. Kullanıcıların erişemediği finansal piyasalarda kredi kullanmaları ve tasarruflarını bu bankalar aracılığıyla sağlamaları pek mümkün görülmemektedir.

Oluşturulan bu boyutlar neticesinde Türkiye genelinde Katılım Bankacılığının FKE değerlerinin gösterildiği Harita 2'ye bakıldığında; 2019 yılına ait KBFKE değerlerinin büyük çoğunluğunun 0.00-0.200 arasında yer alarak düşük düzeye sahip olduğu görülmektedir. İstanbul, Ankara, Konya, Rize ve Kocaeli illerinin yüksek KBFKE değerine sahip olduğu ve orta KBFKE değerine sahip illerin ise benzer şekilde büyük bir çoğunluğu oluşturduğu saptanmıştır. Bunun yanında Bursa, Yalova, Düzce, Karabük,

M. Gündüz, Y. Özyıldııım, “Finansal Kapsayıcııı̆ın Gelişmesinde Katıım Bankacılığının Rolü: Katııım Bankacılığı Finansal Kapsayıcılık Endeksinin Hesaplanması”, BDDK Bankaclık ve Finansal Piyasalar Dergisi, 14, (2), 2020, 119-144 
Aksaray, Karaman, Nevşehir, Kayseri, Gaziantep, Erzincan, Trabzon ve Siirt illeri ise orta Katılım Bankacılığının FKE düzeyine sahiptir.

\section{Harita 2. Türkiye'de 2019 Yılı İçin Katılım Bankacılığına Ait FKE Değerleri}

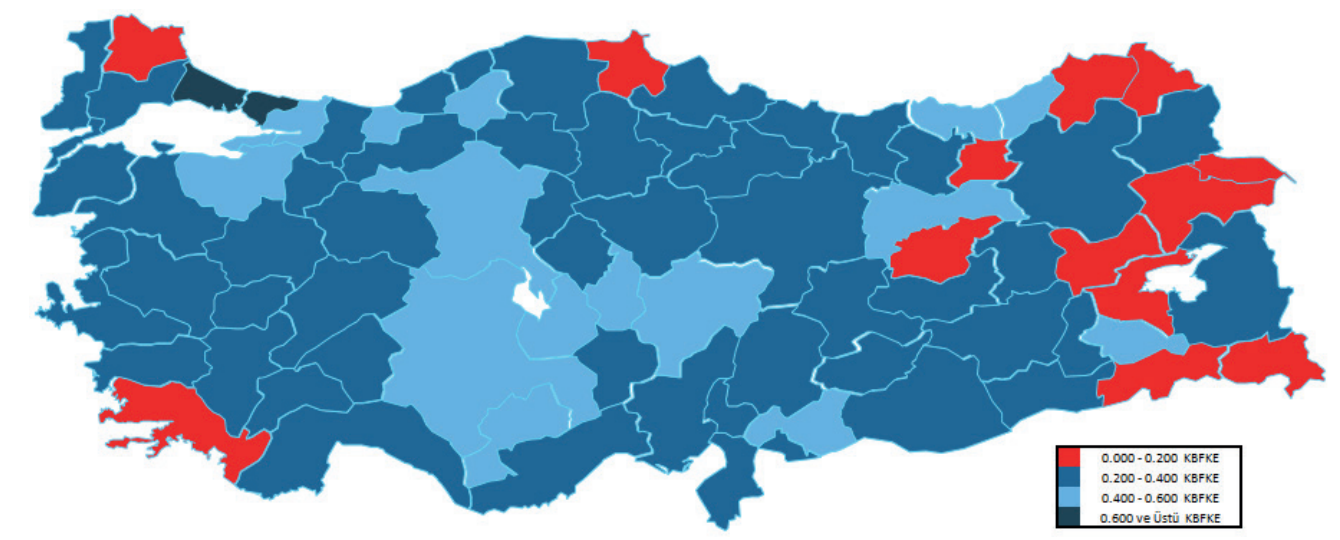

2019 yılı için düzey değerde elde edilen ilk beş ve son beş ilin KBFKE değerleri Tablo 6'da gösterilmektedir. Katılım Bankacılığının FKE hesaplamasında kullanılan düzey değerlerinin yer aldığı tabloda her bir boyutun hesaplanma aşamasında nasıl katkısının olduğu veboyutlar arasındaki değişimler göstergelerle incelenebilmektedir.

\section{Tablo 6.illk Beş ve Son Beş İlin 2019 Yılı İçin Düzey Değerleri}

\begin{tabular}{|c|c|c|c|c|}
\hline & iller & $\begin{array}{c}\text { 100.000 Kişi Başına } \\
\text { Şube Sayısı }\end{array}$ & Kişi Başı Nakdi Kredi & $\begin{array}{c}\text { Kişi Başı Tasarruf Mev- } \\
\text { duatı }\end{array}$ \\
\hline \multirow{5}{*}{ 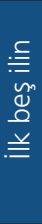 } & ISTANBUL & 1.000 & 1.000 & 1.000 \\
\hline & ANKARA & 0.534 & 0.611 & 0.346 \\
\hline & KONYA & 0.569 & 0.314 & 0.459 \\
\hline & RiZE & 0.487 & 0.487 & 0.326 \\
\hline & KOCAELI & 0.617 & 0.361 & 0.316 \\
\hline \multirow{5}{*}{ 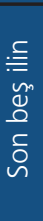 } & HAKKÂRI & 0.000 & 0.000 & 0.000 \\
\hline & ARTVIN & 0.000 & 0.002 & 0.006 \\
\hline & TUNCELI & 0.000 & 0.008 & 0.020 \\
\hline & SINOP & 0.000 & 0.009 & 0.029 \\
\hline & ARDAHAN & 0.000 & 0.029 & 0.009 \\
\hline
\end{tabular}

Kaynak: BDDK ve TÜIK' ten elde edilen veriler kullanılarak yazarlar tarafından hesaplanmıştır.

Tablo 6 incelendiğinde KBFKE hesaplamasında kullanılan boyut değerlerine göre ilk beş sırada yer alan iller sırasıyla İstanbul, Ankara, Konya, Rize ve Kocaeli'dir. İstanbul ilinin tüm değer bakımından birinci sırada olduğu görülmektedir. 100.000 kişi başına şube sayısı boyutunda İstanbul'dan sonra Kocaeli ili ikinci sırada yer alırken Ankara ilinin de kişi başı nakdi kredi boyutunda ikinci sırayı aldığı dikkat çekmektedir. 
Konya ilinde ise kişi başına tasarruf miktarı boyutunda İstanbul ilinden sonra ikinci sırada yer alarak tasarrufların yüksek oranda Katılım Bankacılığı kuruluşlarında sağlandığına işarettir. Son beş sırayı paylaşan iller ise Hakkâri, Artvin, Tunceli, Sinop ve Ardahan'dır. Bu iller içerisinde 100.000 kişi başına şube sayısı boyutunun sıfır olması bu illerde Katılım Bankacılığı faaliyetlerini gerçekleştirebilecek bir şubenin olmadığını ifade etmektedir. Diğer boyutlar bakımından da oldukça düşük değerlere sahip olmaları buralarda bu hizmetlerden çok düşük seviyede yararlanıldığını göstermektedir.

Genel anlamda Katılım Bankacılığı hizmetleri her geçen seneyle birlikte gelişimini sürdürmekte ve faaliyet alanını genişletmektedir. Bu sayede finansal kapsayıcılık düzeyinin artmasına katkı sağladığı düşünülmektedir.

\section{Sonuç}

Öncelikle çalışmada Türkiye'nin geleneksel bankacılık sisteminin içinde yer alan katılım bankacılığının finansal piyasaverileri kullanılarak katılım bankacılığının finansalkapsayıcılık endeksini ölçmek amaçlanmıştır. Çalışmayı özgün kılan husus, 20072019 yılları arasında Türkiye'nin 81 ili için katıım bankacılığının finansal kapsayıcılık endeksi'nin hesaplanmış olmasıdır. Hesaplanan endeks sayesinde illerde yaşayan bireylerin katılım bankacılığı anlamında faaliyette bulunan finansal piyasalara ne ölçüde eriştikleri ve kullandıkları ortaya çıkarılmıştır. Böylece hesaplanan bu endeks ile özellikle dini gerekçeleri öne sürerek kendisini finansal piyasalardan dışlayan veya dışlanmış kabul eden bireylerin, katılım bankacılığı yoluyla finansal piyasalara erişimleri ve kullanımları hakkında bilgiler verilmiştir. Bu sayede Türkiye için katılım bankacılığının finansal kapsayıcılık endeksi hesaplanmış ve literatüre kazandırılmıştır.

Çalışmanın amaçları doğrultusunda finansal kapsayıcılığa ilişkin olarak yapılan bu araştırmada aşağıda belirtilen sorulara cevap aranmıştır.

- Türkiye'de katılım bankacılığının dahil olduğu finansal sistem ne kadar kapsayıcıdır?

- Türkiye'de iller arasında katılım bankacılığı finansal kapsayıcılık endeksi açısından farklılık var mıdır?

- Türkiye'de katıım bankacılığı sisteminin gelişimi finansal kapsayıcılığı artırır mı?

Oluşturulan endeksler neticesinde kapsayıcı bir finansal sistem oluşturmak için tüm kullanıcıların finansal ürün ve hizmetlere erişebilmesinin önündeki engelleri kaldırmak ve süreçleri iyileştirmek hedefi içinde olunması gerekmektedir. 
Türkiye gibi müslüman nüfusun yoğun bir şekilde hayatlarını sürdürdüğü ülkelerde katılım bankaları gün geçtikçe faaliyetlerini arttırmakta ve önem kazanmaktadır. Bu nedenle finansal kapsayıcılık endeksi oluşturulurken katılım bankacılığının ürün ve hizmet yelpazesinin de değerlendirilmesi çok boyutlu bir endeksin oluşturulmasına zemin hazırlayacak ve finansal kapsayıcılığın ölçülmesinde daha sağlıklı bir yol alınmasını sağlayacaktır.

Finansal kapsayıcılığın yaygınlaşmasıyla birlikte daha düşük FKE'ne sahip illerde ekonomik refahın artacağı beraberinde yoksulluğu azaltan etkisinin olabileceği düşünülmektedir. Dolayısıyla finansal kapsayıcılığın gelişmesiyle beraber düşük kapsayıcılık düzeyine sahip illerin ekonomik büyümeye katkı sağlayacağı bu sayede illerin ekonomik olarak ilerlemesine katkıda bulunacağı tahmin edilmektedir. Açıkcası bu durum yetişkin bireylerin tasarruflarını finansal piyasalar aracılığıyla gerçekleştirmesiyle birlikte piyasada bir nakit akışının sağlanacağına işarettir. Beraberinde nakit ihtiyacı güden piyasaların canlanmasına ve ticari teşebbüste bulunan girişimcilere desteğin sağlanmasına imkân tanıyacaktır.

\section{Tartışma ve Öneri}

Daha kapsayıcı bir finansal piyasa oluşturabilmek için gittikçe ivmelenen bir gelişim gösteren katılım bankacılığı sistemi iletasarrufların bu sistem içerisinde değerlendirilebileceği düşünülebilir. Böylece dini değerlerini gerekçe göstererek kendini klasik bankacılık sistemi dışında tutma eğilimi gösterenlerin tasarruflarını yastık altı tabir edilengerek döviz gerekse de altına yöneltmelerinin önüne geçilebileceği değerlendirilebilir. Bu da finansal piyasa dışında kalan kaynakların katılım bankacılık sistemi ile finansal piyasalara dahil edilmesine neden olabilecektir. Bunun için bireylerin kolaylıkla katılım bankacılığı sistemine erişimleri ve finansal piyasaları daha fazla kullanımlarının sağlanması beklenmektedir. Ancak belirli bir gelişme gösteren katıım bankacılığı sistemindeki bu gelişme hızı finansal kapsayıcılığı beklenen düzeyde artırmakta mıdır?. Bu sorunun cevabı üzerinde tartışmak ve katılım bankacılığı sisteminin tercih nedenleri üzerinde düşünülmesi gerekmektedir. 


\section{Kaynakça}

1. Arora, Rashmi Umesh (2010), Measuring Financial Access, Griffith University, Discussion Paper Economics 7, ISSN1837-7750, s.1-50.

2. Beck, Thorsten, Demirguc-Kunt Aslı, Levine Ross (2005), "Law and Firms' Access to Finance", American Law and Economics Review, s.210-223.

3. Beck, Thorsten, Demirguc-Kunt Aslı, Levine Ross (2007), "Finance, Inequality And The Poor", Journal of Economic Growth, forthcoming, s.1-9.

4. Beck, Thorsten, Demirguc-Kunt Aslı, Martinez Peria Maria Soledad (2006), Banking Services for Everyone? Barriers to Bank Access And Use Around The World, The World Bank Economic Review, 22(3), s.1-60.

5. Beck, Thorsten, Demirguc-Kunt Aslı, Martinez Peria Maria Soledad (2005), Reaching out: Access to and Use of Banking Services Across Countries, Journal of Financial Economics, 85, s.1-52.

6. Burgess, Robin, Pande Rohini (2004), "Can Rural Banks Reduce Poverty? Evidence from the Indian Social Banking Experiement", American Economic Review, 95, s.1-30.

7. Chakravarthi, Rangarajan (2008), Report of the Committee on Financial Inclusion, Government of India.

8. Chakravarty, Satya R, Pal Rupayan (2010), Measuring Financial Inclusion: an Axiomatic Approach, Indira Gandhi Institute of Development Research (IGIDR) WP-2010-003, s.1-38.

9. Crabtree, Steve (2010), Religiosity Highest in World's Poorest Nations, Washıngton, D.C.31.

10. Demirguc-Kunt, Asll, Klapper Leora (2012), Measuring Financial Inclusion: The Global Findex Database, Policy Research Working Paper 6025, The World Bank, s.1-61.

11. Demirguc-Kunt, Aslı, Klapper Leora, Randall Douglas (2013), Islamic Finance and Financial Inclusion Measuring Use Of And Demand For Formal Financial Services Among Muslim Adults, Policy Research Working Paper 6642, The World Bank, s.1-45. 
12. Demirgüc-Kunt, Aslı, Klapper Leora, Singer Dorothe, Oudheusden Peter Van (2015), The Global Findex Database 2014: Measuring Financial Inclusion Around the World, Policy Research Working Paper 7255, World Bank, s.1-97.

13. Er B., Ergün T. ve Güneysu Y. (2016). Katılım Bankalarının Finansal Erişime Etkisi: Türkiye Örneği. International Joint Conference on Islamic Economics and Finance, İstanbul

14. Gallup Center for Muslim Studies. (2010), Religious perceptions in America: With an in-depth analysis of US attitudes toward Muslims and Islam.

15. Gupte, Rajani, Venkataramani Bhama, Gupta Deepa (2012), “Computation Of Financial İnclusion Index For India", Procedia-Social and Behavioral Sciences, 37, s.133-149.

16. Gündüz, Murat, Özyıldırım Yunus (2019), "Türkiye'de Illere Göre Finansal Kapsayıcılık Endeksinin Ölçülmesi", Bankacılık Dergisi, Sayı 111, s.52-70.

17. Honohan, Patrick (2007), "Cross Country Variation In Household Access To Financial Services", Paper prepared for the World Bank Conference on Access to Finance, March s.1-38.

18. IFSB. (2019). Published standards. Erişim Tarihi: 25.11.2020, https://www. ifsb.org/download.php?id=5358\&lang=English\&pg=/sec06.php

19. Işık, İhsan (2011), Dünyada ve Türkiye'de Finansal Hizmetlere Erişim ve Finansal Eğitim, Türkiye Cumhuriyeti Merkez Bankası. Ankara.

20. Kempson, Elaine (1994), Outside The Banking System: A Review Of Households Without A Current Account, Research Paper, Great Britain. Social Security Advisory Committee, London: H.M.S.O.

21. Kempson, Elaine, Whyley Claire (1999), Kept Out Or Opted Out? Understanding And Combating Financial Exclusion, The Policy Press. Bristol, s.1-60

22. Mersland, Roy, Øystein Strøm Reidar (2009), "Performance And Governance In Microfinance İnstitutions", Journal of Banking \& Finance, 33(4), s.662-669.

23. Mohieldin, Mahmoud, Iqbal Zamir, Rostom Ahmed, Fu Xiaochen (2011), The Role Of Islamic Finance In Enhancing Financial Inclusion In Organization Of Islamic Cooperation (OIC) Countries, Policy Research Working Paper 5920, World Bank, Washington DC, s.1-61. 
24. Morgan, Peter J., Pontines Victor (2014), Financial Stability and Financial Inclusion, ADBI Working Paper Series, (No.488), s.1-18.

25. Naceur, Sami Ben, Barajas Adolfo, Massara Alexander (2015), Can Islamic Banking Increase Financial Inclusion?, IMF Working Paper 15/31, s.1-41.

26. PBAT (2019). Member Banks. Participation Banks Association of Turkey. Retrieved from: http://www.tkbb.org.tr/memberbanks, erişim tarihi: 30.09.2020

27. Peachey, Stephen, Alan Roe (2006), "Access to Finance, Measuring the Contribution of Savings Banks", World Bank Savings Institute.

28. Prathap, Sangeetha K (2011), "Financial İnclusion of Fisher Households in Coastel Kerala-Role Of Microfinance", Thesis. Cochin University of Science and Technology.

29. Sarma, Mandira (2008), "Index of Financial Inclusion", Working paper 215, Indian Council for Research on International Economic Relations, s. 1-20.

30. Sarma, Mandira (2010), "Index of Financial Inclusion", CITD Discussion Paper, s. 10-18.

31. Sarma, Mandira, Pais Jesim (2011), "Financial Inclusion And Development: A Cross Country Analysis", Journal of International Development, 23(5), s.613628.

32. Seman, Junaidah Abu (2016), Financial Inclusıon: The Role Of Fınancial System And Other Determınants, Salford Business School University of Salford, United Kingdom. s. 1-272.

33. Seven, U., Yassa, A. D. ve Yılmaz, F. (2020). Finansal Kapsayıcılık: Türkiye ve Dünya Karşılaştırması (No. 2004). Research and Monetary Policy Department, Central Bank of the Republic of Turkey.

34. Türkiye Bankalar Birliği (2019), Bankaların Aktiflere Göre Sektör Payları. https://www.tbb.org.tr/tr/bankacilik/banka-ve-sektor-bilgileri/4

35. United Nations Development Programme (2019), Islamic Finance and Impact Investing,https://www.undp.org/content/undp/en/home/sustainable-development-goals.htmlerişim tarihi: 01.10.2020

36. World Bank (2005), World Development Indicators. https://databank.worl- 
dbank.org/source/world-development-indicators

37. World Bank (2014), Finansial Inclusion. Global Financial Development Report. International Bank for Reconstruction and Development.

38. Yorulmaz, Recep (2013). Construction of a regional financial inclusion index in Turkey. Journal of BRSA Banking and Financial Markets, 7(1), 79-101.

39. Zhijun, Wang (2007), "Financial Exclusion: The Experiences Of The United Kingdom", World Economy Study, s.2-12.

40. Zulkhibri, Muhamed (2016), "Financial İnclusion, Financial İnclusion Policy And Islamic Finance", Macroeconomics and Finance in Emerging Market Economies, 9(3), s.303-320. 